Cell type specificity in DNA damage response

doi:10.1016/i.mrfmmm.2005.12.018

Copyright ( 2006 Elsevier B.V. All rights reserved.

\title{
Tissue specific mutagenic and carcinogenic responses in NER defective mouse models
}

\author{
Susan W.P. Wijnhoven ${ }^{\mathrm{a}}$, Esther M. Hoogervorst ${ }^{\mathrm{a}}$, Harm de Waard ${ }^{\underline{b}}$, Gijsbertus T.J. van \\ der Horst ${ }^{\underline{b}}$ and Harry van Steeg ${ }^{\underline{a}, *}$
}

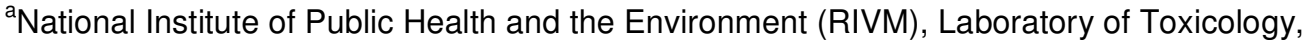
Pathology and Genetics, PO Box 1, 3720 BA, Bilthoven, The Netherlands

${ }^{\mathrm{b}} \mathrm{MGC}$, Department of Cell Biology and Genetics, Erasmus Medical Center, Rotterdam, The Netherlands

* Corresponding author. Tel.: +31 274 2102; fax: +31 2744446.

\begin{abstract}
Several mouse models with defects in genes encoding components of the nucleotide excision repair (NER) pathway have been developed. In NER two different sub-pathways are known, i.e. transcription-coupled repair (TC-NER) and global-genome repair (GG-NER). A defect in one particular NER protein can lead to a (partial) defect in GG-NER, TC-NER or both. GGNER defects in mice predispose to cancer, both spontaneous as well as UV-induced. As such these models (Xpa, Xpc and Xpe) recapitulate the human xeroderma pigmentosum (XP) syndrome. Defects in TC-NER in humans are associated with Cockayne syndrome (CS), a disease not linked to tumor development. Mice with TC-NER defects (Csa and Csb) are except for the skin - not susceptible to develop (carcinogen-induced) tumors. Some NER factors, i.e. XPB, XPD, XPF, XPG and ERCC1 have functions outside NER, like transcription initiation and inter-strand crosslink repair. Deficiencies in these processes in mice lead to very severe phenotypes, like trichothiodystrophy (TTD) or a combination of XP and CS. In most cases these animals have a (very) short life span, display segmental progeria, but do not develop tumors. Here we will overview the available NER-related mouse models and will discuss their phenotypes in terms of (chemical-induced) tissue-specific tumor development, mutagenesis and premature aging features.
\end{abstract}

\section{Role of NER in the prevention of gene mutations and cancer}

\subsection{General introduction into NER}

The genetic information of the cell is not carried by a stable, rigid macromolecule, but by the rather vulnerable DNA. Numerous physical and chemical agents of both endogenous as well as environmental origin continuously challenge its integrity. Alterations in the DNA of somatic cells - from small point mutations affecting only one base pair to large deletions or rearrangements - increase with age [1] and are primarily responsible for the age-related increase in cancer rate. An immediate effect of DNA damage may be physical interference with the cellular machines responsible for gene transcription [2] and [3]. As a result, inappropriate changes in gene expression may occur, leading to cellular dysfunction. In proliferative cells, DNA damage may additionally block DNA replication and prevent cell division [2] and [3]. To counteract such deleterious effects, the cell is equipped with a wide variety of genome care taking mechanisms including various DNA repair machineries with partially overlapping substrate specificity. The vital importance of DNA repair mechanisms as caretakers of the genome is best demonstrated by the consequences of their absence or dysfunction in a variety of rare autosomal recessive disorders. A striking example is the repair pathway nucleotide excision repair (NER). Three different photosensitive diseases are associated with this pathway: (i) xeroderma pigmentosum (XP), (ii) Cockayne Syndrome (CS) or (iii) trichothiodystrophy (TTD). The diagnostic features of XP are, besides the 
photosensitivity: a dry scaly skin (xeroderma), abnormal pigmentation in sun-exposed skinareas (pigmentosum), and a 1000-fold increased risk of developing UV-induced skin cancer, primarily basal and squamous cell carcinomas and melanomas. Besides this skin cancer predisposition, a 10-20-fold increased risk of developing several types of internal cancers before the age of 20 has been described [4]. CS and TTD do not show any increased cancer risk, but rather attribute hallmarks of premature aging, as manifested by severe mental and physical retardation. In addition to the progeroid symptoms observed in both CS and TTD, further TTD-features are brittle hair and nails and ichthyosis.

Complementation studies have shown the involvement of seven genes in XP (XPA through $X P G)[4]$ and two genes in CS (CSA and CSB) [5] and [6]. A subset of mutations in XPB, XPD and $X P G$ can lead to the combined phenotype of XP and CS. In contrast to classical CSpatients, these patients are cancer prone [4]. TTD has been associated with mutations in XPB, XPD and the recent discovered TFB5 subunit of TFIIH [4] and [7]. To understand how mutations in different NER factors, or even how different mutations in the same NER factor, cause these different diseases, detailed knowledge on the function of these factors is needed.

\subsection{NER at the molecular level}

Nucleotide excision repair is capable of removing numerous types of helix-distorting lesions, including UV-induced photoproducts. Other substrates for NER include reactive oxygen species (ROS)-induced 5',8-purine cyclodeoxynucleotides [8] and [9] and bulky lesions, which could for example originate from polycyclic aromatic hydrocarbons (as present in tobacco smoke and smog). NER functions by a "cut and patch"-like mechanism in which damage recognition, local opening of the DNA helix around the lesion, damage excision and gap filling occur in successive steps (Fig. 1). NER is composed of two subpathways, global genome NER (GG-NER) and transcription-coupled NER (TC-NER), which share the same core mechanism but differ in the way lesions are recognized. 


\section{GG-NER}

Bulky adducts<smiles>[131IH]</smiles>

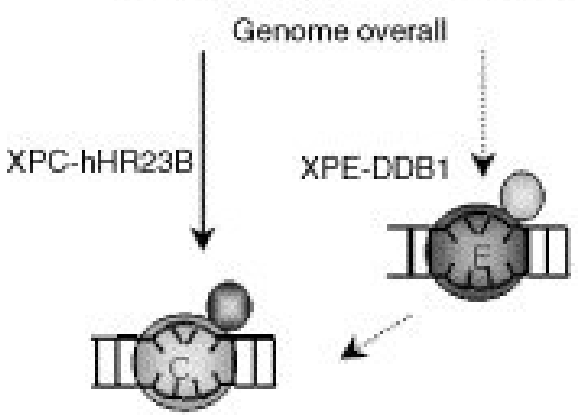

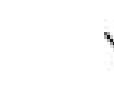

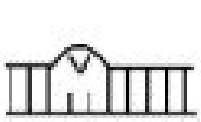

TFIIH

$\mathrm{XPG}$

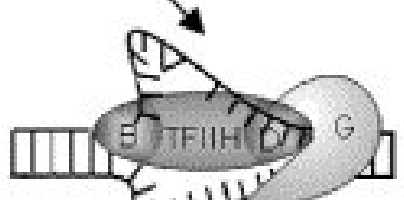

$\mathrm{CDP}_{8}$

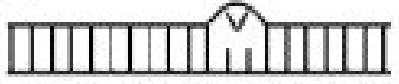

Transcribed DNA
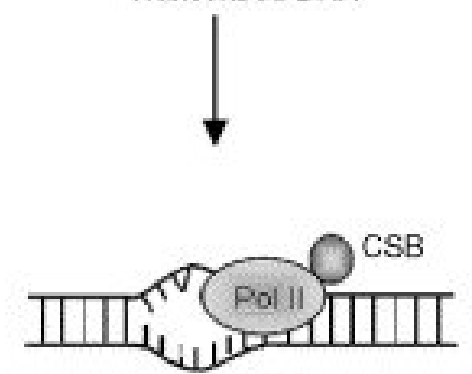

CSA

TFIIH

$\mathrm{XPG}$
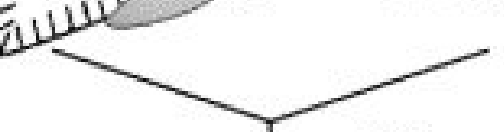

E)

XPA

RPA
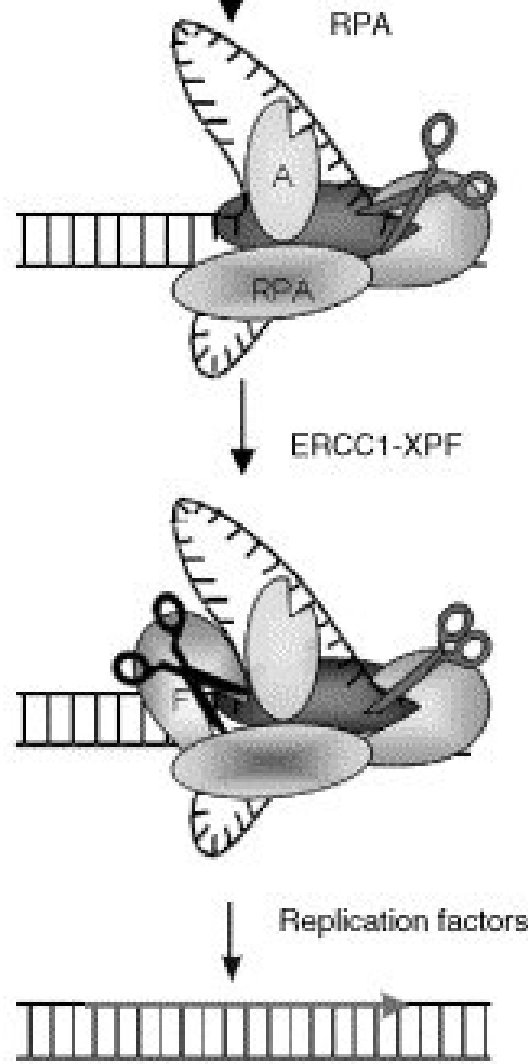

Fig. 1. Nucleotide excision repair. This figure shows the principle of nucleotide excision repair (NER) and its two subpathways, global genome NER (GG-NER) and transcription-coupled NER (TC-NER) and the various proteins involved. 
The first step in GG-NER is damage recognition by the heterodimer XPC/hHR23B [10], [11] and [12], which binds with higher affinity to helix-distorting DNA lesions than to non-damaged double stranded DNA (dsDNA) [13] and [14]. Since damage recognition is highly dependent on the degree of DNA helix distortion, DNA lesions that only mildly disturb the helical structure are poorly recognized by XPC/hHR23B and, as a consequence, are inefficiently repaired by GG-NER. One such lesion is the UV-induced CPD. GG-NER of this photolesion is greatly enhanced by the damaged DNA binding complex (DDB) [15], [16] and [17] composed of DDB1 (p125) and DDB2 (p48 or XPE). p48 accumulates at local damage in the absence of XPA or XPC [18] and stimulates XPC, XPA and replication protein A (RPA) binding to damaged DNA (see below). Moreover, accumulation of XPC on damaged DNA containing only CPDs is dependent on p48, suggesting that p48 acts upstream of XPC [19].

The second mechanism by which NER can be initiated is via damage in the transcribed strand of active genes that can arrest the transcriptional machinery. The consequences of a stalled RNA polymerase are enhanced for lesions such as CPDs that are slowly (or even not) repaired by GG-NER. Repair of such lesions via transcription-coupled NER (TC-NER) [20], [21], [22] and [23] is initiated by stalling of an elongating RNA polymerase II upon a lesion [24]. The cross-talk between a blocked RNA polymerase and the actual repair reaction, as well as the way in which the damage is made accessible, is still a matter of debate. However, it is clear that somehow $C S A, C S B$-and $X A B 2$ gene products are involved in these steps [25], [26] and [27]. It has been shown that cell lines mutated for the CSA or the CSB gene or with an inactivated XAB2 protein are deficient in performing TC-NER. As a consequence, these cells fail to recover RNA synthesis after induction of UV damage, indicating that the transcription block remains [3] and [26]. Since damage recognition in TC-NER does not depend on helix distortion, but instead on blockage of RNA polymerase II, the spectrum of lesions recognized by TC-NER and GG-NER differs. For example, whereas CPDs are poorly (and in rodents almost not at all) recognized and repaired by GG-NER, these lesions efficiently block transcription and accordingly are efficiently repaired by TC-NER [20]. Subsequent to damage recognition by either NER subpathway, the multisubunit transcription factor TFIIH and the structure-specific endonuclease XPG are recruited to the lesion [12] and [28]. In vitro reconstituted NER requires only the recruitment of XPG at this step [10]. TFIIH contains the XPB and XPD proteins that act as $3^{\prime}-5^{\prime}$ and $5^{\prime}-3^{\prime}$ helicases, respectively, and function in local unwinding of the DNA around the lesion [29], [30], [31], [32] and [33]. Initial stability of the open structure is guaranteed by the presence of the XPG protein [30] and [34]. After verification of the damage by the XPA protein [12], this open structure is further stabilized by XPA and RPA [30], [35], [36] and [37]. In a reconstituted system it has been shown that XPC-hHR23B is no longer present in this complex [10]. In line with these findings, EMSA experiments show that XPC-hHR23B is replaced by XPA and RPA [38]. Finally, the ERCC1/XPF endonuclease assembles [10] and [12] and, together with XPG, cleaves $3^{\prime}$ and $5^{\prime}$ of the lesion respectively, thereby excising a 24-32 nt single stranded DNA (ssDNA) fragment containing the DNA damage [34], [39] and [40]. Using the undamaged strand as a template, filling of the ssDNA gap is performed by the DNA replication machinery, consisting of RPA, proliferating cell nuclear antigen (PCNA), replication factor C (RFC) and DNA polymerases $\delta$ and $\varepsilon$ [41], [42] and [43]. Finally, the resulting nick is sealed by DNA ligase I [44] and [45].

NER is not a separated module, but is integrated in a network of processes. Also the individual NER factors have functions outside the context of NER. Defects in these functions might well contribute to the features of $\mathrm{XP}, \mathrm{CS}$ and TTD patients.

\subsection{Involvement of NER factors in other (DNA repair) processes}

Cells with a mutation in the CSB gene are sensitive for oxidative stress [46], suggesting that transcription coupled repair is not restricted to classical NER lesions. Oxidative DNA damage is preferentially repaired via the BER pathway. It is, however, largely unclear whether BER comprises a TCR component. In fact it is also unknown whether TCR factors like CSA, CSB, XPG, XPB, XPD, TFB5 are only needed for removal/back-tracking of the stalled RNApolymerase from the damaged site in order to make the lesion accessible to other repair factors, or that they are also needed for a transcription coupled repair reaction. 
The 10-subunit TFIIH complex was originally purified and characterized as a basal transcription initiation factor for RNA polymerase II transcribed genes [47]. Three different subunits (XPB, XPD and TFB5) of this complex are directly linked to XP, CS and TTD [4] and [7]. Indeed, it has been shown that TFIIH is required in both GG-NER and TC-NER [29] and [32]. The recent discovered differential phosphorylation of the XPB subunit of TFIIH after UV [48], suggests an active switch between the function of TFIIH in repair and transcription. Recently, the multifunctionality of TFIIH has been complemented with documented involvements in activated RNA polymerase II transcription [49] and [50], in basal transcription initiation of rRNA genes by RNA polymerase I [51] and [52] and a possible role of the CAK subcomplex in cell cycle [47] and [53]. The ERCC1/XPF complex is a NER factor with engagements in interstrand cross-link repair, since deficiency for this structure-specific endonuclease causes sensitivity for cross-linking agents. Moreover detailed cell biological and molecular studies have shown a function in homologous recombination and perhaps also in double strand break repair [54] (and references therein).

The other endonuclease, XPG has been reported to bind to and stimulate the activity of base excision repair proteins [55]. Moreover, in yeast a function of XPG in transcription elongation has been suggested [56].

Specific function of the several factors in the NER reaction, together with the extra non-NER related functions, nicely correlates with the different syndromes. Mutations that only hamper global genome repair, or are present in the core NER reaction (XPC, XPE, XPA and specific subclasses of mutations in $X P B, X P D, X P F, X P G)$ underlie the cancer prone XP. This can be explained by the fact that lesions in the total genome, when replicated, can cause mutations and thereby underlie cancer. In contrast, mutations that only affect the TCR pathway (CSA, $C S B$ ) do not lead to an increased cancer incidence, rationalized by the fact that GG-NER is still active repairing the bulk of the lesions. Moreover, defects in TCR cause a sensitized response to DNA damage (e.g. lower thresholds for sunburn) that likely removes damaged cells by apoptosis [57], [58], [59], [60] and [61].

Defects in TCR (CSA, CSB) will lead to a compromised transcription and thereby might disturb the cellular homeostasis. This might lead via p53-dependent and independent pathways to cell death (apoptosis) or a permanent cell cycle arrest (senescence). Increased cell death, caused by hampered transcription (as a result of defective TCR or caused by mutations in the transcription factors themselves) likely cause the progeroid features of CS and TTD. Alternatively, increased cell death due to a combination of a NER and an interstrand crosslink repair defect can cause similar phenotypes. Finally, the TTD specific characteristics (brittle hair, nails and ichthyosis) can be attributed to a reduced stability of the TFIIH complex in differentiating cells, causing a transcription defect in cells late in the differentiation process.

\section{NER mouse models and their spontaneous phenotypes}

As outlined in the previous section, different factors involved in NER and/or related pathways (repair and/or transcription) do have, when affected, an enormous impact on individual phenotypes, like cancer and ageing. Most of these phenotypes came apparent from studies using mouse models that mimic genetic changes found in patients with defective NER functions. A summary of the currently available mouse mutant models and their accompanying phenotypes is given in the next section and in Table 1. 
Table 1.

Spontaneous phenotype of viable NER-deficient mice

\begin{tabular}{|c|c|c|c|c|c|c|c|c|}
\hline $\begin{array}{l}\text { Mouse } \\
\text { model }\end{array}$ & $\begin{array}{l}\text { Affected repair } \\
\text { pathway }\end{array}$ & $\begin{array}{l}\text { Enhanced tumor } \\
\text { response }\end{array}$ & Reference & $\begin{array}{l}\text { Enhanced } \\
\text { MF }^{\mathrm{a}}\end{array}$ & Tissue + locus & Reference & $\begin{array}{l}\text { Accelerated aging/developmental } \\
\text { problems }\end{array}$ & Reference \\
\hline \multirow[t]{2}{*}{$X p a^{-/-}$} & GG-NER/TC-NER & Yes, liver & [65], A & Yes & $\begin{array}{l}\text { Liver, kidney, } \\
\text { lacZ }\end{array}$ & [66], B & Shorter life span, no pathology & A \\
\hline & & & & No & Spleen, Hprt & [74] & & \\
\hline $\mathrm{Xpc}^{-1-}$ & GG-NER & Yes, lung & [72], A & Yes & Spleen, Hprt & [74] & Shorter life span & A \\
\hline$m H R 23 B^{-1-}$ & GG-NER & n.a. & & n.d. & & & Very short life span/embroynic lethality & [79] \\
\hline $\begin{array}{l}X p e \\
(D D B 2)^{-/-}\end{array}$ & GG-NER & Yes, various & [80] & n.d. & & & & \\
\hline \multirow[t]{2}{*}{$\mathrm{Csb}^{-/-}$} & TCR/transcription & No & [81] & No & $\begin{array}{l}\text { Liver, kidney, } \\
\text { lacZ }\end{array}$ & B & Normal life span, mild pathology & [81], A \\
\hline & & & & & Spleen, Hprt & [74] & & \\
\hline $\mathrm{Csa}^{-1-}$ & TC-NER & No & [82] & n.d. & & & & \\
\hline$X p g^{-1-}$ & TCR/transcription & n.a. & & n.d. & & & Very short life span, maximum 3 weeks & [84] \\
\hline$X p g^{\operatorname{sex} 15}$ & TCR/transcription & n.r. & & n.d. & & & Normal life span & {$[86]$} \\
\hline$X p g^{\text {D811stop }}$ & TCR/transcription & No & & n.d. & & & Very short life span, maximum 5 weeks & {$[86]$} \\
\hline$X p g^{E 791 A}$ & TCR/transcription & n.r. & & n.d. & & & Normal development & {$[87]$} \\
\hline$X p d^{T T D}$ & NER/transcription & No & $\frac{[93]}{[94]}$ and & No & $\begin{array}{l}\text { Liver, kidney, } \\
\text { lacZ }\end{array}$ & $\mathrm{B}$ & Shorter life span, aging and CR pathology & {$[93]$ and } \\
\hline$X p b^{-1-}$ & NER/transcription & n.a. & & n.d. & & & Impaired embryonic development & [95] \\
\hline $\operatorname{Ercc1}^{-1-}$ & $\mathrm{NER} / \mathrm{ICL}$ & n.a. & & n.d. & & & Very short life span, maximum 4 weeks & $\frac{98]}{[99]}$ and \\
\hline $\operatorname{Ercc1}^{\Delta / 1-}$ & NER/ICL & No & & Yes & Liver, lacZ & $\mathrm{B}$ & Short life span of 4-6 months & {$[99]$} \\
\hline$X p f^{\mathrm{m} / \mathrm{m}}$ & $\mathrm{NER} / \mathrm{ICL}$ & n.a. & & n.d. & & & Very short life span, maximum 3 weeks & {$[104]$} \\
\hline
\end{tabular}

A: S.W.P. Wijnhoven et al., unpublished results; B: M.E.T. Dollé et al., personal communication; n.a.: not applicable, mice live too short for tumors to develop; n.r.: not reported but mice live long enough for tumors to develop; n.d.: not determined; c.r.: caloric restriction.

${ }^{a}$ Enhanced mutation frequencies when compared to wild type mice. 


\subsection{Mouse models with a defect in GG-NER}

Patients belonging to the XP-A complementation group are in general completely devoid of any NER activity. Both GG-NER and TC-NER are defective caused by base substitutions, deletions and splice site mutations in the XPA gene, frequently in a compound heterozygous manner [62]. To mimic this human XPA null activity, complete knock-out $X \mathrm{pa}^{-/-}$mice were generated by two independent groups [63] and [64]. $\mathrm{Xpa}^{-/-}$mice develop normally, are healthy, fertile and show no enhanced mortality up to an age of 18 months [65]. However, recently we found that $\mathrm{Xpa}^{-/-}$mice in a pure C57BL/6 genetic background have a slightly shorter lifespan than their wild type controls (S.W.P. Wijnhoven, unpublished results). The incidence of spontaneous liver tumor development (mostly hepatocellular adenomas, see Fig. 2) was found to be slightly increased in older Xpa-deficient mice (S.W.P. Wijnhoven, unpublished results; [65]). With respect to other aging-related pathology, $\mathrm{Xpa}^{-/-}$mice appeared to have the same phenotype as C57BL/6 control wild type mice.

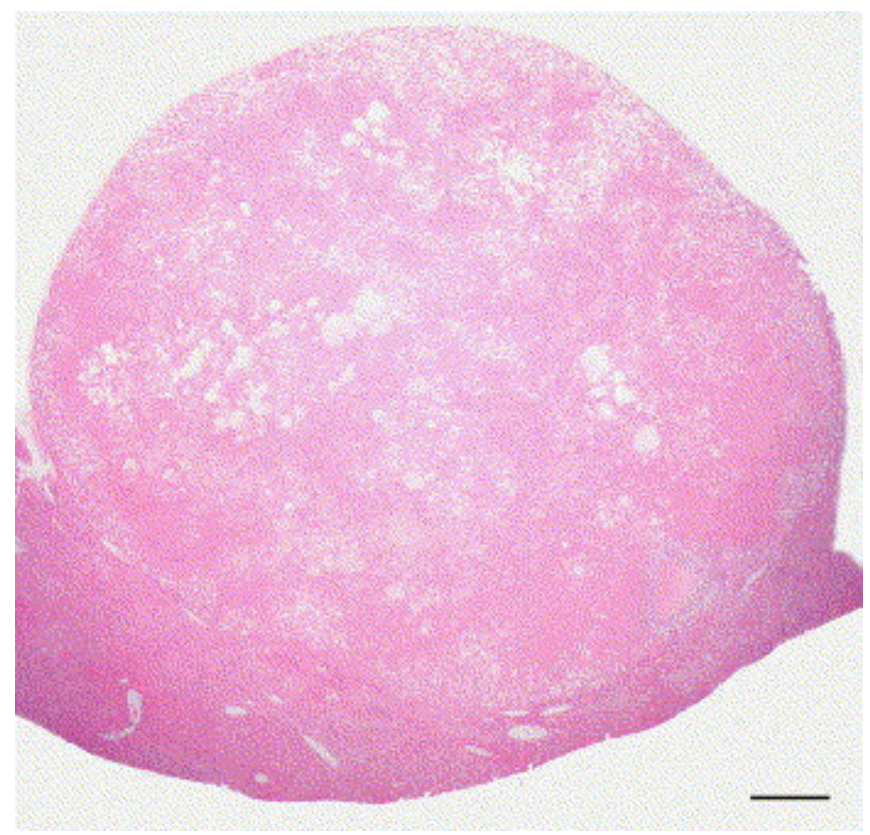

Fig. 2. Hepatocellular adenoma arisen in a male $\mathrm{Xpa}^{-/-}$mouse. Nodular HCA compressing adjacent liver tissue spontaneously. Bar represents $500 \mu \mathrm{m}$.

After crossbreeding Xpa-deficient mice with the pUR288 lacZ reporter mice, an increased level of lacZ mutations was found in livers of 9-16 months old Xpa mice, but not $\mathrm{Csb}^{-1-}$, $X p d^{T T D}$ and wild type mice (M.E.T. Dollé, personal communication; [66]). This indicates that the accumulation of lac $Z$ mutations (mostly point mutations) in the liver are predictive for development of spontaneous tumors at later stages in live, at least in $\mathrm{Xpa}^{-/-}$mice.

Although no spontaneous neurological abnormalities could be observed in older Xpa-deficient mice, a delayed neuromotor recovery and increased cognitive dysfunction was visible following experimental brain trauma [67].

Within GG-NER the XPC protein is, together with HR23B, responsible for recognition of the DNA damage (see previous section and [68]). Two independently generated knockout mouse models for $X p c$ [69] and [70] were shown to be viable and to develop normally. Although initially, no increased incidence of spontaneous tumors was observed in Xpc-deficient animals until the age of one year [69], [70] and [71], a more recent study of Hollander et al. [72] showed an enhanced frequency of lung tumor development in $\mathrm{Xpc}^{-/-}$mice. All aged (16-17 months) $X_{p c}^{-/-}$mice (in a mixed background of 75\% C57BL/6 and 25\% Ola129) developed multiple spontaneous lung tumors with a minority progressing to non-small cell lung 
adenocarcinoma, whereas only $5 \%$ of wild type littermates developed such tumors [72]. Furthermore, preliminary results of an ongoing lifespan study with $X p c$ mice show that in a pure C57BL/6 background macroscopically lesions are also visible in lungs of $X_{p c} c^{-/-}$mice (S.W.P. Wijnhoven, unpublished results). In addition, and in contrast to previous results [71] and [72], we observed for the first time a statistical significant shorter life span for $\mathrm{Xpc}^{-/-}$mice and more interestingly, also for $X p c^{+/-}$mice as compared to the life span of their wild type littermates. Histopathological analyses of tissues of these mice are still ongoing. Allelic insufficiency for the $X p c$ gene has been previously reported with respect to an increased predisposition to UV-B-induced skin cancer in aged $\mathrm{Xpc}^{+/-}$mice [73] as well as to spontaneous Hprt mutant frequencies in splenocytes [74]. These data can possibly be explained by a compromised DNA repair capacity in $\mathrm{Xpc}^{+/-}$cells. However, no enhanced lymphoma incidence was reported in Xpc-deficient mice, suggesting that spontaneous Hprt mutant frequencies in the spleen are not reliable for prediction of tissue-specific carcinogenic responses in mice. In order for tumors to develop, both gene mutations and chromosomal rearrangements (that can not be recovered at the Hprt locus) are probably necessary. Therefore, lac $Z$ studies (proven to be more predictable for spontaneous tumor development) will be performed in the near future in spleen and lung of $X p c$ mice of different ages to further elucidate the spontaneous (cancer) phenotype of $\mathrm{Xpc}^{-/-}$and $\mathrm{Xpc}^{+/-}$mice.

Another damage recognition factor known to be involved in GG-NER is DDB2/XPE (see Fig. 1). It is specifically involved in the repair of UV photoproducts, especially CPDs. Furthermore, it has recently been shown [75] that in human XPE cells DDB2 first targets and accelerates repair of 6-4 PPs as well. Mice with a disruption of this gene $\left(D d b 2^{-1-}\right.$ mice) were generated recently [76], [77] and [78] and apart from the expected skin tumor development upon UVirradiation, these mice have a pronounced spontaneous cancer phenotype. A significantly reduced life span was found possibly owing to a high incidence of developing "spontaneous" tumors at later stages of life (between 20 and 25 months; [77]). The tumor spectrum was quite broad, but consistent with the broad expression pattern of DDB2, i.e. lymphomas, lung tumors, breast and cervical carcinomas were found [77]. A clear UV cancer-prone phenotype was found in $D d b 2^{+/-}$mice, providing evidence for a gene dosage effect for Ddb2 [76], [77] and [78]. In addition, a transgenic mouse model ectopically expressing Ddb2 was generated, in which enhanced expression of the protein delayed the tumor phenotype of the mice and repair of both CPDs and 6-4PP was improved in dermal fibroblasts [78].

Finally, mice deficient for HR23B were generated [79]. This protein is found in complex with the XPC protein, but its function in NER is unknown. The phenotype of $m H R 23 B^{-1-}$ mice, i.e. impaired embryonic development and a high rate $(90 \%)$ of intra-uterine or neonatal death, completely differs from the "true GG-NER" models [79]. Furthermore, surviving $m H R 23 B^{-1-}$ animals display a variety of abnormalities including retarded growth, facial dysmorphology and male sterility, indicating that $\mathrm{mHR} 23 \mathrm{~B}$ has an important role in development which is distinct from XPC and other GG-NER proteins. A possible function of HR23B (and HR23A) protein in NER might be the governing of XPC stability via partial protection against proteasomal degradation [80].

In general, the spontaneous tumor-phenotype in the majority of GG-NER deficient mouse models suggests that this sub-pathway of NER prevents spontaneous tumorigenesis. Interestingly, different tissues seem to be target for tumor development, i.e. liver in $\mathrm{Xpa}^{-/-}$, lung in $X p c^{---}$and a miscellaneous pattern was found in $X p e^{-/-}$mice. Apparently, endogenous DNA damage in combination with factors that sensor substrate specificity (XPC and XPE) determine the ultimate tumor outcome. In the lung preferentially XPC substrates (reactive oxygen species, ROS?) are the underlying effectors, whereas other (possibly non-NER) substrates, preferentially recognized by the XPE protein, in other tissues are causative to the tumor spectrum found in Xpe null mice. As for the liver tumor phenotype in Xpa mice: it might be that endogenous (NER-specific) lesions are not repaired any longer in transcribed strands of tumor-associated genes, since liver tumors are absent in Xpc mice (only GG-NER deficient). These considerations are attractive to initiate further studies on the role of (NERspecific) DNA lesions in tissue-specific tumorigenesis. 


\subsection{Mouse models with a defect in TC-NER}

Two mouse models for the TC-NER disorder CS, exclusively involving transcription-coupled repair, were generated. In Csb-deficient mice, a truncation mutation in the CSB gene of a CSB patient [81] was mimicked, while in $\mathrm{Csa}^{-/-}$mice the mouse Csa gene was knocked out by interrupting exon 2 [82]. $\mathrm{Csb}^{-/-}$as well as $\mathrm{Csa}^{-/-}$mice appeared to be viable and exhibited all of the CS repair characteristics: UV sensitivity, inactivation of TC-NER, unaffected GG-NER and inability to resume RNA synthesis after UV exposure. Other human CS features such as growth failure and neurological dysfunction were only present in the mouse models in a mild form. A recent life span study revealed that although young $\mathrm{Csb}^{-/-}$mice (until the age of 13 weeks) appeared to have growth characteristics that are quite similar to C57BL/6 controls, a minimal weight gain was observed in older $C s b^{-/-}$mice, resulting in a statistically lower body weight compared to wild types, during their entire life span (S.W.P. Wijnhoven, unpublished results). Unexpectedly, the median life span of $\mathrm{Csb}^{-1-}$ mice was identical to that of $\mathrm{C} 57 \mathrm{BL} / 6$ controls, both in male and female mice (S.W.P. Wijnhoven, unpublished results).

Furthermore, similar to human CS patients, no enhanced spontaneous tumorigenesis could be observed in Csb-deficient mice. In addition, some age-related pathology differences were visible in $\mathrm{Csb}^{-/-}$mice, for instance in the kidney (renal karyomegaly, Fig. $3 \mathrm{~A}$ ) and the eye (retinal atrophy, Fig. 3B). Apparently, endogenously generated DNA damages in actively transcribed genes lead to enhanced pathology in specific target tissues, rather then to tumor development as is found in GG-NER defective mouse models (see above).

(A)
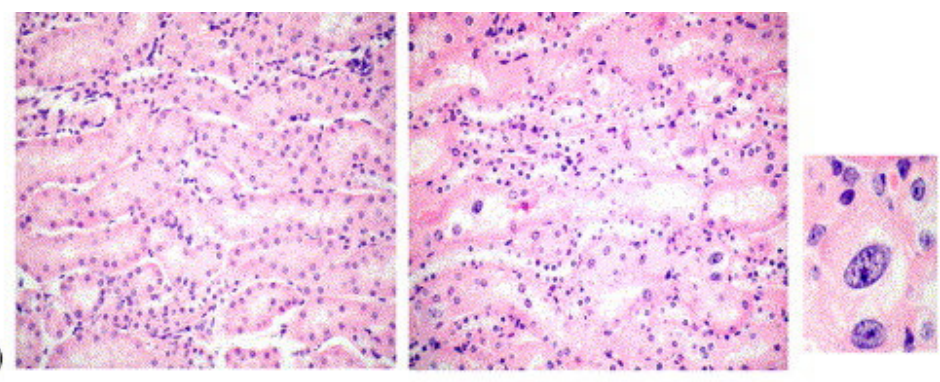

(B)
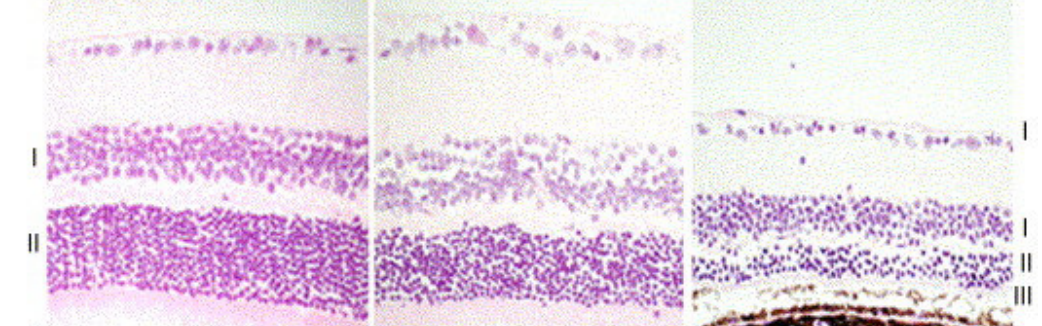

III

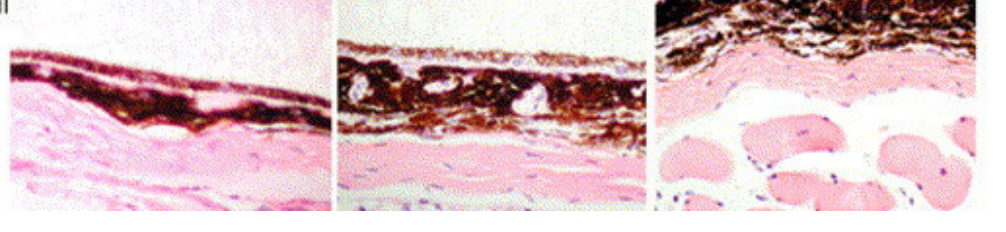

Fig. 3. Aging-related pathology of $C s b^{-/-}$mice. (A) Renal karyomegaly. Left panel: pars recta of the proximal renal tubules of a wild type C57BL/6 mouse with little variation in nuclear size. Middle panel: the same area of a $\mathrm{Csb}^{-/-}$mouse showing an irregular histological picture with scattered enlarged and frequently oval shaped nuclei. Right: higher magnification of tubular cells with karyomegaly. (B) Atrophy of the retina. Left panel with inner nuclear layer (I), outer nuclear layer (II) and rods and cones layer (III) of a young adult C57BL/6 mouse. Below the dark stained pigment layer. Mid panel shows slight retinal atrophy as frequently observed in old C57BL/6 mice. The three layers (I-III) are smaller and show loss of cellular mass. Right panel showing distinctly decreased diameter of the retina in a 2-year old $\mathrm{Csb}^{-/-}$mouse. The rods and cones have almost disappeared and decrease in cellularity is obvious in the inner and (especially) outer nuclear layers. 
Recently, a new TC-NER and transcription factor was discovered, XAB2, that associates with the CSA, CSB and RNA polymerase II as well as the XPA protein. To further elucidate the function of this XAB2 protein in vivo, two different mutations were introduced into the $X A B 2$ gene in mice. Both deletion mutants, one of the region encompassing the promoter and exons 1-4 and the other of the C-terminal 162 amino-acids, were embryonic lethal in mice, indicating that $X A B 2$ has an essential function in mouse development [83].

The XPG protein is a structure-specific endonuclease in NER that cleaves $3^{\prime}$ of the lesion. However, mutations in the human XPG gene can result not only in XP, but also in early onset of CS in some patients, pointing to a defect in TCR. This phenotypical heterogeneity was also found in the several different Xpg-deficient and mutant mouse models. Complete Xpgdeficient mice, generated by deletion of exon 3 of the mouse Xpg gene, exhibit postnatal growth failure and undergo premature death, similar to human CS features [84]. Further examination of cerebellum of these Xpg-deficient mice showed a large number of atrophic Purkinje cells, and their dendritic trees were smaller and shorter than in their wild type littermates [85]. However, deletion of exon 15 of this gene (Xpg $\Delta$ ex15, truncation of the last 183 amino acids) resulted in mice that develop normally. XpgD811stop homozygous mice with a C-terminal deletion of 360 amino acids exhibited growth retardation and a short life span, mimicking human CS but in a slightly milder form than the Xpg null mutant mice [86]. This indicates that the severity of the CS phenotype is influenced by the length of the truncated Xpg protein. Introduction of a E719A mutation in exon 11 of the Xpg gene, inactivating the endonuclease catalytic site, but leaving the remainder of the protein intact, resulted in a normally developing mouse with no obvious defect in class switch recombination [87]. In recent reports it has been proposed that XPG is involved in several distinctive pathways outside NER, like BER and transcription [88], [89] and [90].

All together we can conclude that, although XPG seems to have a more or less identical function in NER as the ERCC1/XPF protein complex, i.e. incision of a stretch of damaged DNA (Fig. 1), the mouse models clearly display different phenotypes (see also below). Further studies are needed to elucidate the exact function of XPG in NER and other processes the protein is definitely involved in.

In summary and in contrast to the GG-NER mouse models, it appears that TC-NER-deficient mouse models do not have an effect on spontaneous tumorigenesis, which is in keeping with the human situation. This finding is further supported in mice by the lack of enhanced spontaneous mutagenesis on Hprt in splenocytes [76] and on lacZ in kidney and liver (M.E.T. Dollé, personal communication) of aging $\mathrm{Csb}^{-/}$mice.

\subsection{Mouse models with a defect in NER and transcription}

Important core components within NER are the XPB and XPD helicases which are subunits of the TFIIH complex implicated as DNA helix opener in both NER and basal transcription initiation. The multi-functionality of both proteins is illustrated by the complex genotypephenotype relationship in human NER patients having different mutations in XPD. Sitespecific XPD germ-line mutations can lead to a variety of syndromes; XP, XP combined with CS, or TTD (see above and Fig. 1).

Consistent with the essential role of XPD in basal transcription, mice with a Xpd null allele, generated by deleting the helicase domains IV-VI, were embryonic lethal in the preimplantation stage [91]. However, the mouse model in which the causative $X P D^{7722 W}$ mutation of a TTD patient is mimicked is viable [92]. $X p d^{R 722 W}$ mice further indicated as $X p d^{T T D}$ mice, just like the TTD patients, do not suffer from enhanced spontaneous tumorigenesis. In a recently published life span study [93], a significantly reduced total number of benign and malignant tumors in aging $X p d^{T T D}$ females compared to wild types was observed, especially lymphomas and pituitary adenomas. Furthermore and consistent with human TTD, the median life span of $X p d^{T T D}$ mice was significantly lower compared to C57BL/6 controls [93] and [94]. Although $X p d^{T T D}$ mice display wide-spread, premature segmental multi-system aging in various different organs [93] and [94], paradoxically also (life span extending) features suggestive of caloric restriction (other than a lower incidence of tumors) were observed in 
aging $X p d^{T T D}$ mice including lower incidence/severity of de-myelination of the peripheral nerve, cataract, thyroid follicular distension, and ulcerative dermatitis [93]. As already mentioned before, no enhanced mutagenesis on the lacZ reporter gene was found in liver and kidney of $X p d^{T T D}$ mice (M.E.T. Dollé, personal communication).

XP-B patients are very rare, and two approaches to mimic the splice mutation affecting the exon of the XP/CS patient XP11BR were unsuccessful in the mouse and led to embryonic lethality. However, a frameshift mutation that mimics the causative XP11BE allele of a human patient appeared to be (partly) viable in the mouse. The non-mendalian inheritance again indicates that gene mutations in these crucial core components of NER and basal transcription easily lead to impaired embryonic development and lethality [95].

In summary, mice with a defect in both NER and transcription are hard to design. Only one clear example is available at present, i.e. the $X p d^{T T D}$ mouse model. The phenotype of these mice is that of accelerating aging, suppression of tumorigenesis accompanied by low spontaneous lacZ mutation levels.

\subsection{Mouse models with a combined defect in NER, interstrand crosslink and/or double strand break repair}

The ERCC1-XPF heterodimer is a structure-specific endonuclease involved in NER but the protein complex is also essential for DNA interstrand crosslink (ICL) repair [96] and class switch recombination (CSR)[97]. Human ERCC1 mutations have never been described so far, but homozygous knockout $\mathrm{ErCC}^{-1-}$ mice, deficient in GG-NER, TC-NER as well as ICL repair, are viable, but have a much more severe phenotype than other NER-deficient mice [98] and [99], consistent with the additional role of the protein outside NER. Although $\mathrm{ErCC1}^{-1-}$ mice develop normally, they quickly display severe wasting resulting in death in the fourth week of life. The most striking defect of $\mathrm{ErCC}^{-1_{-}}$mice is liver failure with accelerated hepatocyte polyploidy, a feature that can be corrected by administration of an ERCC1 transgene [100]. Many of the features of the $E r c c 1^{-1-}$ mice are reminiscent of normal mammalian aging, including ataxia, kyphosis, ostopenia, weight loss, skin atrophy sarcopenia and hepatocellular polyplodization [101]. Recently, it was reported that $\mathrm{ErCC1}^{-/-}$mice also display hematopoietic aging as both basal hematopoiesis and reserve capacity under stress were severely reduced in these mice, consistent with that found in normal aged mice [102]. However, the premature liver polyploidy, as was reported in $\mathrm{ErCC}^{-/-}$mice, differs from the normal aging-related process, as the observed dramatic increased p21 levels in Ercc1 ${ }^{-1-}$ livers were absent in livers of normal aging mice with the same amount of polyploidy [103]. The combination of a knockout allele with a truncated version of Ercc1, missing only seven amino acid residues at the C-terminus ( $\operatorname{Ercc1}^{\Delta 7 /-}$ ) [99] delays the onset of the premature aging phenotype and extends the maximal lifespan to about 4-6 months.

Mice with a defect in the XPF factor more or less display the same phenotype as found in the different Ercc1 models. Xpf-mutant mice were generated by introducing a G-445 mutation resulting in a stop codon in exon 8 of the mouse Xpf gene [104]. Although this mutation is compatible with normal development in humans, a severe postnatal growth effect was observed in $X p f^{m / m}$ mice, resulting in death approximately 3 weeks after birth. Consistent with the phenotype of $\mathrm{Ercc}^{-1 /}$ mice, histological examination revealed that livers of $X p f^{\mathrm{m} / \mathrm{m}}$ mice contained abnormal cells with enlarged nuclei [104].

LacZ mutation analysis in livers of 23-week old $\operatorname{Ercc}^{\Delta{ }^{4 /-}}$ mice revealed a significant increase in both point mutations as well as size-change (translocation/recombination) mutations compared to sibling controls (M.E.T. Dollé, personal communication). Since in $\mathrm{Xpa}^{-/-}$mice the increase in mutations at older age was caused primarily by an increase of only point mutations, the result in $\operatorname{Ercc1}^{\Delta 7 /-}$ mice reflects their additional defect in ICL repair. Considering the mutation types found in the XP models ( $X p a$ and $X p c$, see above) compared to those in $E r c c 1^{\Delta 7 /-}$ mice, one might argue that accumulating point mutations preferentially lead to cancer, whereas size change mutations will ultimately end up in segmental accelerating aging. Support for this hypothesis comes further from a study with aging wild type mice, in 
which large rearrangements in lac $Z$ preferentially accumulate at later stages of life, even in non-tumorous post-mitotic tissue [1].

\subsection{Double mutant mouse models}

Finally, several double mutant or knock-out NER mice were developed to gain more insight in the relationship between the different NER (-associated) processes. For example, double mutant mice for CS and XP, i.e. Csb/Xpa and Csb/Xpc mice display very severe growth impairment, suffer from neurological problems and die before weaning [95] and [105]. Furthermore, a recent study with $X p g / X p a$ double mutant mice revealed the same severe phenotype of growth retardation and a very short life span, suggesting that XPG can have functions similar to CSB [106]. Probably CSB (and XPG) are involved in additional transcription-coupled processes. The $X p d^{T T D} / X p a$ double mutant was found to be compatible with normal embryogenesis, but was associated with increased neonatal lethality, suggesting that the mice had a reduced tolerance to stress [94]. The life span of this mouse model is only 3 weeks encompassing a greatly accelerating aging phenotype. In general it can be concluded that when pure DNA repair defects, as observed in Xpa and Xpc mice, are combined with (mild) defects in transcription initiation $\left(X p d^{T T D}\right)$ or transcription elongation $(C s b)$, the original cancer phenotype of the XP models is greatly suppressed and replaced by phenotypes that are suggestive for accelerated segmental aging. A clear example that deficiency in TCR is suppressive to tumor development was recently found in cancerpredisposed Ink4a/ARF mice. Development of lymphomas and fibrosarcomas was found to be clearly reduced (60\% reduction) after crossing Ink4a/ARF mice with $C s b$-deficient mice [107].

\section{Tissue-specific mutagenic and carcinogenic effects in NER-deficient mice after external exposure}

A defect in GG-NER results in a spontaneous tumor phenotype, whereas defects in TC-NER, NER/transcription and NER/ICL repair do not. To gain more insight into the effect of a defect in the NER pathway(s) on carcinogen-induced tumorigenesis, NER deficient mouse models were exposed to genotoxic carcinogens. These studies are, for obvious reasons, restricted to the viable NER mouse models, like mice deficient or mutant for $X p a, X p c, X p d^{T T D}, X p e, C s a$ and $C s b$. The tissue-specific mutagenic and carcinogenic responses in skin, liver, urinary bladder, spleen, lung and other tissues will be discussed below and are summarized in Table 2 . 
Table 2.

Tissue-specific mutagenic and carcinogenic responses of NER deficient mice

\begin{tabular}{|c|c|c|c|c|c|c|}
\hline Tissue & Genotype & Treatment & $\begin{array}{l}\text { Enhanced } \\
\text { tumor } \\
\text { response }^{\mathrm{a}}\end{array}$ & Reference & $\begin{array}{l}\text { Enhanced } \\
\text { mutagenesis }^{\text {a }}\end{array}$ & Reference \\
\hline \multirow[t]{10}{*}{ Skin } & $X p a^{-/-}$ & UV radiation & Yes & $\frac{[63]}{[64]}$ and & & \\
\hline & $X p c^{-/-}$ & UV radiation & Yes & $\frac{[69]}{[73]}$ and & & \\
\hline & $X p d^{I I D}$ & UV radiation & Yes & {$[110]$} & & \\
\hline & $X p e^{-/-}$ & UV radiation & Yes & [76] & & \\
\hline & $\mathrm{Csa}^{-1-}$ & UV radiation & Yes & $\overrightarrow{82}$ & & \\
\hline & $C s b^{-1-}$ & UV radiation & Yes & [81] & & \\
\hline & $X p a^{-/-}$ & DMBA paint & Yes & $\frac{[63]}{[64]}$ and & & \\
\hline & $X p d^{T T D}$ & DMBA paint & Yes & [110] & & \\
\hline & $X p e^{-1-}$ & DMBA paint & No & [76] & & \\
\hline & $C s b^{-1-}$ & DMBA paint & Yes $^{\underline{b}}$ & [81] & & \\
\hline \multirow[t]{6}{*}{ Liver } & $X p a^{-/-}$ & $\begin{array}{l}\text { AFB1 i.p. } \\
\text { injection }\end{array}$ & Yes & [124] & & \\
\hline & $X p a^{-/-}$ & 2-AAF diet & Yes & $\frac{[125]}{[126]}$ and & Yes, LacZ & $\frac{[125]}{[126]}$ and \\
\hline & $C s b^{-1-}$ & 2-AAF diet & No & [126] & Yes, LacZ & [126] \\
\hline & $X p c^{-1-}$ & 2-AAF diet & Yes & [126] & Yes, LacZ & [126] \\
\hline & $X p c^{-/-}$ & $\begin{array}{l}\text { AAF i.p. } \\
\text { injection }\end{array}$ & Yes & [127] & & \\
\hline & $X p c^{-/-}$ & $\begin{array}{l}\text { NOH-AAF i.p. } \\
\text { injection }\end{array}$ & Yes & [127] & & \\
\hline \multirow[t]{3}{*}{$\begin{array}{l}\text { Urinary } \\
\text { bladder }\end{array}$} & $X p a^{-/-}$ & 2-AAF diet & No & $\begin{array}{l}{[125] \text { and }} \\
{[126]}\end{array}$ & No & $\begin{array}{l}{[125] \text { and }} \\
{[126]}\end{array}$ \\
\hline & $X p c^{-1-}$ & 2-AAF diet & No & {$[126]$} & Yes, LacZ & {$[126]$} \\
\hline & $\mathrm{Csb}^{-1-}$ & 2-AAF diet & No & [126] & No & [126] \\
\hline \multirow[t]{2}{*}{ Spleen } & $X p a^{-/-}$ & $\mathrm{B}[\mathrm{a}] \mathrm{P}$ gavage & Yes & $\begin{array}{l}{[67] \text { and }} \\
{[130]}\end{array}$ & $\begin{array}{l}\text { Yes, LacZ and } \\
\text { Hprt }^{\underline{c}}\end{array}$ & $\frac{[130],[131]}{\text { and [132] }}$ \\
\hline & $C s b^{-/-}$ & $\mathrm{B}[\mathrm{a}] \mathrm{P}$ gavage & No & [134] & $\begin{array}{l}\text { No, LacZ and yes, } \\
\text { Hprt }^{\underline{c}}\end{array}$ & [134] \\
\hline \multirow[t]{5}{*}{ Lung } & $X p a^{-/-}$ & $\begin{array}{l}\mathrm{B}[\mathrm{a}] \mathrm{P} \\
\text { intratracheal }\end{array}$ & Yes & [135] & & \\
\hline & $X p a^{-1-}$ & $\mathrm{B}[\mathrm{a}] \mathrm{P}$ gavage & No & [132] & No & [132] \\
\hline & $X p a^{-1-}$ & $\mathrm{B}[\mathrm{a}] \mathrm{P}$ diet & No & [136] & No & [136] \\
\hline & $X p c^{-/-}$ & $\begin{array}{l}\mathrm{N}-\mathrm{OH}-\mathrm{AAF} \text { i.p. } \\
\text { injection }\end{array}$ & Yes & [127] & & \\
\hline & $X p c^{-1-}$ & $\begin{array}{l}\text { AAF i.p. } \\
\text { injection }\end{array}$ & Yes & [127] & & \\
\hline
\end{tabular}

DMBA: 7,12-dimethylbenzanthracene; B[a]P: benzo[a]pyrene; AFB1: aflatoxin B; AAF:

acetylaminofluorene.

${ }^{\text {a }}$ As compared with untreated control mice.

${ }^{b}$ Only significant in tumor yield, but not in latency time.

${ }^{c}$ Hprt mutant frequencies were only measured in spleen. 


\subsection{Skin}

NER disorders are characterized by hypersensitivity of the skin to sunlight. Furthermore, patients with XP develop skin cancers on exposed sites, whereas CS and TTD patients do not. From UV studies in NER-deficient mice it became apparent that - like XP patients - Xpa, $X p c$ and Xpe-deficient mice are susceptible to UV-induced skin cancer [63], [64], [73], [76], [78], [108] and [109]. However, in contrast to patients, the $X p d^{T T D}, C s a^{-1-}$ and $C s b^{-1-}$ models also appeared more susceptible to develop UV-induced cancer than their littermate controls [81], [82] and [110], although a higher cumulative dose and a longer latency time was required as compared with $\mathrm{Xpa}^{-/-}$or $\mathrm{Xpc}^{-/-}$mice [82] and [111]. This indicates that - like spontaneous tumorigenesis - efficient GG-NER is more important than efficient TC-NER in the protection against UV-induced skin tumor development. The discrepancy between mouse and human CS and TTD could be related to the more efficient repair of cyclobutane pyrimidine dimers (CPDs) by GG-NER in human skin fibroblasts compared to rodents [112] and [113].

In contrast to mice, GG-NER in humans is possibly able to compensate for a defect in TCNER, leading to unchanged cancer predisposition in TTD and CS patients. In addition, TTD and CS patients have a reduced life span and frequent hospitalization might protect them from exposure to sunlight.

To study the effect of a NER deficiency on UV-induced mutagenesis and carcinogenesis in vivo, several mutation studies have been performed at the $p 53$ and Hras gene of UV-induced skin tumors in NER-proficient and -deficient mice. UV-induced skin tumors in NER-proficient mice expressed a very typical mutation spectrum at $p 53$. The great majority of the mutations are found at dipyrimidine sites at the non-transcribed strand (NTS) [114], [115], [116], [117], [118] and [119]. In NER-deficient mice, the prevalence of $p 53$ mutations in the TS versus NTS is dependent on the specific pathway which is absent. Tumors of Xpc-deficient mice predominantly carry mutations in the NTS [115] and [120], whereas tumors of mice deficient in the Csb gene show predominantly p53 mutations in the TS [121]. Complete absence of $\mathrm{NER}$ - as found in $\mathrm{Xpa}^{-/-}$mice - results in the presence of $p 53$ mutations in TS as well as NTS $(70 \%$ and $30 \%$, respectively) [121] and [122]. In addition to p53 mutations, tumors of TCNER deficient Xpa and Csb mice - but not WT or Xpc $c^{-/-}$mice - accumulate mutations in the Hras gene, exclusively on the TS [121] and [123]. Furthermore, Hras mutations are only found in squamous cell papillomas, a tumor type not found in WT or $\mathrm{Xpc}^{-/}$mice. Evidently, a TCNER deficiency results in the formation of Hras mutations and therefore, the formation of squamous cells papillomas.

Next to UV, chemically induced skin tumor analyses have been performed with $X p a^{-/-}$, $X p d^{T T D}, X p e^{-/-}$and $C_{s b} b^{-/-}$mice. These mice were all topically exposed to 7,12-dimethyl-1,2benz[a]anthracene (DMBA). Xpa-deficient mice appeared highly sensitive to the toxic as well as carcinogenic effects of DMBA [63] and [64]. Toxicity was also observed in TC-NER deficient $\mathrm{Csb}^{-/-}$mice, supporting the hypothesis that accumulation of DNA damage at the transcribed strand (TS) of genes leads to increased toxicity and apoptosis, resulting in the elimination of cells having specifically damage in the TS. In addition, $\mathrm{Csb}^{-1-}$ mice were susceptible to develop skin tumors, although a higher DMBA cumulative dose and a longer latency time than Xpa mice was required, as was found after UV exposure [81]. The tumor response of the NER/transcription-deficient $X p d^{T T D}$ mice was intermediate of that observed in $\mathrm{Xpa}^{-/-}$and $\mathrm{Csb}^{-/-}$mice [110], suggesting that protection against DMBA-induced skin tumors is mainly accomplished by GG-NER. Interestingly, repair of DMBA-induced DNA damage is not likely to be mediated by the XPE/DDB2 protein as Xpe-deficient mice showed no increased sensitivity to develop DMBA-induced skin tumors as compared to WT mice [76]. Apparently, the XPE protein has clear substrate specificity at least in mice, i.e. UV-induced CPDs.

\subsection{Liver}

As described above, $\mathrm{Xpa}^{-/-}$mice are predisposed to develop spontaneous liver tumors, which are preceded by elevated levels of lac $Z$ mutations. Upon exposure to carcinogenic agents, $X \mathrm{pa}^{-/-}$mice are even more sensitive to develop hepatocellular tumors. Exposure to aflatoxin 
B1 (AFB1), $p$-cresidine as well as 2-acetylaminofluorene (2-AAF) resulted in an increased tumor incidence as compared to their WT counterparts [124], [125], [126] and [127]. Interestingly, the liver tumor incidence was even higher in $\mathrm{Xpc}^{-1-}$ mice than in $\mathrm{Xpa}^{-1-}$ mice after exposure to $300 \mathrm{ppm} 2-\mathrm{AAF}$ (53\% versus $25 \%$ ) and $2500 \mathrm{ppm} p$-cresidine $(78 \%$ versus $36 \%)$ [126, H. van Steeg, unpublished results]. In contrast, no liver tumors were found in $\mathrm{Csh}^{-1-}$ mice [126]. Apparently, a defect in GG-NER is associated with internal cancer predisposition in mice after exposure to liver carcinogens. In contrast, a TC-NER deficiency seems to have a protective role. Again, this might be attributed to either efficient repair of DNA damage at transcribed sequences by GG-NER [128], or by enhanced levels of apoptosis in cells which accumulate DNA damage at transcribed sequences. In this respect, it would be interesting to analyze the prevalence of mutations in the TS versus NTS of target genes in the future. However, the $p 53$ gene is not a suitable candidate since we have previously shown that p53 mutations are absent in 2-AAF-induced liver tumors of $X \mathrm{pa}^{-/-}$mice [125].

LacZ mutant frequencies were significantly increased in $\mathrm{Xpa}^{-/-}, \mathrm{Xpc}^{-/-}$as well as $\mathrm{Csb}^{-/-}$mice as compared to their untreated counterparts after 12 weeks of 2-AAF exposure [126] and [129]. Interestingly, mutation levels between $\mathrm{Xpa}^{-/-}, \mathrm{Xpc}^{-/-}$and $\mathrm{Csb}^{-/-}$livers were all comparable, in contrast to the ultimate tumor response. Apparently, lac $Z$ mutant frequencies in liver of 2-AAF exposed mice are indicative for exposure to 2-AAF, but not predictive for tumor development.

\subsection{Urinary bladder}

2-AAF is an agent which targets both liver and urinary bladder when administrated orally, although urinary bladder tumors are found with lower frequencies [126]. No statistic significant increase in tumor response was found in 2-AAF-exposed Xpa-, Xpc- or Csb-deficient mice as compared with WT mice. Still though, $\mathrm{Xpa}^{-/-}$and $X p \mathrm{c}^{-/}$mice developed slightly more tumors than $\mathrm{Csh}^{-/-}$mice (incidence of $20 \%, 21 \%$ and $6 \%$, respectively). In contrast, $p$-cresidine exposure in $\mathrm{Xpc}^{-1-}$ mice did result in a significantly increased urinary bladder tumor response as compared with WT or $X \mathrm{pa}^{-/-}$mice [H. van Steeg, unpublished results]. This indicates that also in bladder, $\mathrm{Xpc}^{-1-}$ mice are more sensitive for carcinogen-induced tumor induction, at least upon exposure to $p$-cresidine.

Mutant frequencies at lac $Z$ upon 12 weeks of 2-AAF exposure were significantly elevated in WT, $\mathrm{Xpa}^{-/-}, \mathrm{Xpc}^{-/-}$as well as $\mathrm{Csb}^{-/-}$mice [126]. $\mathrm{Xpc}^{-/-}$mice showed the highest levels of lacZ mutants, reflecting the GG-NER deficiency in these cells. However, focusing on urinary bladder tumor development, the mutant frequencies did not predict tumorigenesis as $\mathrm{Csb}^{-1-}$ mice showed a mutant frequency comparable with WT and $\mathrm{Xpa}^{-/-}$mice.

\subsection{Spleen}

NER-deficient mice do not develop lymphomas spontaneously. To analyze carcinogeninduced mutagenic and/or carcinogenic responses in spleen, several exposure studies have been performed with benzo[a]pyrene (B[a]P), $N$ - $n$-butyl- $N$-nitrosurea (BNU) and DMBA. Of these, B[a]P has been analyzed most extensively. Sub-chronic (9 months) oral exposure of $X \mathrm{pa}^{-/-}$mice resulted in an increased incidence and shorter latency time of lymphomas as compared with WT mice [65] and [130]. In accordance, in the spleen of Xpa-deficient mice, mutant frequency levels of the non-transcribed lacZ as well as the actively transcribed Hprt gene clearly exceeded those measured in WT mice [130], [131] and [132]. This increase in Hprt gene mutation in $\mathrm{Xpa}^{-1-}$ mice was also observed upon exposure to BNU [133]. Interestingly however, exposure to high levels of BNU resulted in Hprt mutation levels similar to WT mice, suggesting that cell death was induced as a result of excessive DNA damage.

Like carcinogen-induced tumor responses found in liver and bladder, the carcinogenic responses in the spleen of $\mathrm{Csb}^{-/-}$mice upon B[a]P exposure were low and similar to WT mice [134]. Also levels of mutations in the lacZ gene were not different from WT mice. In contrast, the mutant frequency in the Hprt gene was clearly elevated, which suggests that $C s b$-deficient cells are not capable to remove B[a]P adducts from actively transcribed genes, whereas DNA damage at non-transcribed sequences is removed as demonstrated by the lac $Z$ mutant 
frequency data. As $\mathrm{Csb}^{-/-}$mice are not tumor prone upon B[a]P exposure, the Hprt gene mutation analyses do not predict tumor outcome in Csb-deficient mice.

\subsection{Lung}

Next to lymphomas, B[a]P also induces lung tumors in Xpa-deficient mice [135], however tumors are only found upon intra-tracheal exposure. No increased incidence of lung tumors was found when $\mathrm{B}[\mathrm{a}] \mathrm{P}$ was administered orally [132], not even in combination with cell proliferation induced by ozone [136]. These studies clearly demonstrate that the route of exposure determines which specific tissue will be affected. B[a]P exposure through the diet resulted in the development of predominantly fore-stomach tumors, gavage administration in lymphomas, and tracheal instillation in lung tumors. Like $\mathrm{Xpa}^{-/-}$mice, $\mathrm{Xpc}^{-/-}$mice are also more sensitive than WT mice to develop lung tumors. After $\mathrm{N}-\mathrm{OH}-\mathrm{AAF}$ treatment by a single i.p. injection, increased lung neoplasia was found in $\mathrm{Xpc}^{-/-}$mice [127], again demonstrating that dose regimens are determinant for tumor target sites as 2-AAF exposure through the diet did not result in lung tumor formation [126].

\subsection{Other sites}

Within the framework of the International Life Sciences Institute (ILSI)/Health and Environmental Sciences Institute (HESI), a large number of exposure experiments have been performed with $\mathrm{Xpa}^{-/-}$mice to validate this model as an alternative for the chronic 2-year cancer bio-assay. In general, $\mathrm{Xpa}^{-/-}$mice are susceptible to develop genotoxic carcinogeninduced tumors [137]. Intriguingly, also some non-genotoxic human carcinogens were tested positive in the Xpa-model, like the hormone DES (pituitary and testis adenomas), the immunosuppressive agent cyclosporin-A (lymphomas) and the peroxisome proliferator WY14,643 (liver tumors). At present it is not clear why $\mathrm{Xpa}^{-/-}$mice are sensitive to these nongenotoxic carcinogens. Furthermore, it remains to be elucidated whether the other GG-NER deficient mice like $X p c$ and $X p e$ have comparable phenotypes.

\section{Concluding remarks}

In general mouse models with defects in NER-related genes recapitulate human syndromes. These range from clear cancer proneness up to segmental premature aging features. Defects in GG-NER lead both in mice and man to cancer prone phenotypes. An interesting observation is that the spontaneous tumor spectra in GG-NER-defective mice are dependent on which gene is affected. Apparently, factors directly involved in damage recognition (XPC and XPE) have different substrate specificities and are possibly, next to NER, also involved in other DNA damage responses. For instance, in $\mathrm{Xpc}^{-/-}$mice a high incidence of lung tumors was found, which were absent in $X \mathrm{pa}^{-/-}$mice. Possibly, lung specific (oxidative) DNA damage is specifically recognized by the XPC protein, whereas the XPA protein is not involved. In

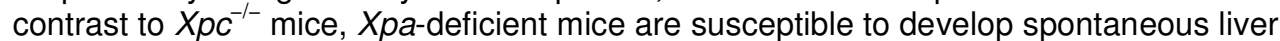
tumors. Further studies are needed to get more knowledge on these tissue specificities.

Defects in TC-NER in humans are associated with Cockayne syndrome (CS), which is characterized by UV-sensitivity, but interestingly not with skin tumor development. TC-NER prevents acute toxic effects by releasing stalled RNA polymerases, which are blocked by (bulky) DNA lesions in actively transcribed genes. Stalled RNA polymerases trigger p53dependent apoptosis and as such possibly contribute to an anti-cancer phenotype. Chemical exposure studies, with TC-NER defective mice, seem to support this vision, as $\mathrm{Csb}^{-/-}$mice are not susceptible to develop carcinogen-induced internal tumors. However, $\mathrm{Csa}^{-/}, \mathrm{Csb}^{-/-}$ and $X p d^{T T D}$ mice do develop skin tumors upon exposure to UV-B. Possibly, GG-NER is far less efficient in mice than in humans to remove UV-induced CPD lesions. Apparently, this does not hold for other bulky lesions. More mechanistic studies are necessary to elucidate why a TC-NER defect in mice leads to UV-induced skin cancer, but not in humans.

In general gene mutation induction precedes tumor development in (NER-deficient) mice. It appears that mutations in the lacZ reporter gene are more reliable early markers for tumor 
development in a particular tissue than, e.g. the endogenous actively transcribed Hprt gene. Enhanced lacZ mutations reflect genotoxic stress in a wide variety of tissues, however, they do not always predict cancer risk in a quantitative manner. In liver and spleen lac $Z$ mutation levels correlate quite well with spontaneous as well as chemical-induced tumors, but this correlation is lacking in bladder, lung, and other tissues. Possibly, the cells in which mutations are detected (probably irreversibly differentiated somatic cells), are not the precursor initiated cells that progress to (malignant) tumors at later stages.

In this review we showed that mice with a defect in NER are subject to various mutagenic and carcinogenic responses in different tissues. These responses depend on which sub-pathway of NER is defect and on which tissue is targeted either by endogenous or exogenous genotoxic compounds. However, some components of NER also contribute to other biological pathways, like transcription and ICL repair. Mice, but also humans, with defects in these genes $\left(X p d^{T T D}, E r c c 1, X p f\right.$ and some $X p g$ variants) have in general (very) short life spans, display segmental progeria and are less or not cancer prone (see Table 1). Further studies are needed to dissect the individual roles of these specific pathways in the acceleration of the aging process and their contemporary tumor suppressive mode of action. Especially, it is far from clear yet what the nature is of the endogenous DNA lesions, which cause the severe phenotypes. Furthermore, the interplay between defective DNA repair systems, cellular senescence, stem cell depletion and apoptosis during aging need further attention.

\section{Acknowledgement}

We would like to thank Dr. Rudolf B. Beems for providing us histopathological pictures. 


\section{References}

[1] M.E. Dollé, W.K. Snyder, J.A. Gossen, P.H.M. Lohman and J. Vijg, Distinct spectra of somatic mutations accumulated with age in mouse heart and small intestine, Proc. Natl. Acad. Sci. U.S.A. 97 (2000), pp. 8403-8408.

[2] A.R. Lehmann, S. Kirk-Bell and L. Mayne, Abnormal kinetics of DNA synthesis in ultraviolet light irradiated cells from patients with Cockayne syndrome, Cancer Res. 3 (1979), pp. 4237-4241.

[3] L.V. Mayne and A.R. Lehmann, Failure of RNA synthesis to recover after UV irradiation: an early defect in cells from individuals with Cockayne's syndrome and xeroderma pigmentosum, Cancer Res. 42 (1982), pp. 1473-1478.

[4] D. Bootsma, K.H. Kraemer, J.E. Cleaver and J.H.J. Hoeijmakers, Nucleotide Excision Repair Syndromes: Xeroderma Pigmentosum Cockayne Syndrome and Trichothiodystrophy (8th ed.), McGraw-Hill, New York (2001).

[5] M.A. Nance and S.A. Berry, Cockayne syndrome: review of 140 cases, Am. J. Med. Genet. 42 (1992), pp. 68-84.

[6] K. Tanaka, K. Kawai, Y. Kumahara, M. Ikenaga and Y. Okada, Genetic complementation groups in Cockayne syndrome, Somat. Cell Genet. 7 (1981), pp. 445-455.

[7] G. Giglia-Mari, F. Coin, J.A. Ranish, D. Hoogstraten, A. Theil, N. Wijgers, N.G. Jaspers, A. Raams, M. Argentini, P.J. Van Der Spek, E. Botta, M. Stefanini, J.M. Egly, R. Aebersold, J.H. Hoeijmakers and W. Vermeulen, A new, tenth subunit of TFIIH is responsible for the DNA repair syndrome trichothiodystrophy group A, Nat. Genet. 36 (2004), pp. 714-719.

[8] P.J. Brooks, D.S. Wise, D.A. Berry, J.V. Kosmoski, M.J. Smerdon, R.L. Somers, H. Mackie, A.Y. Spoonde, E.J. Ackerman, K. Coleman, R.E. Tarone and J.H. Robbins, The oxidative DNA lesion 8,5'-(S)-cyclo-2'-deoxyadenosine is repaired by the nucleotide excision repair pathway and blocks gene expression in mammalian cells, J. Biol. Chem. 275 (2000), pp. 22355-22362.

[9] I. Kuraoka, C. Bender, A. Romieu, J. Cadet, R.D. Wood and T. Lindahl, Removal of oxygen free-radical-induced $5^{\prime}, 8$-purine cyclodeoxynucleosides from DNA by the nucleotide excision-repair pathway in human cells, Proc. Natl. Acad. Sci. U.S.A. 97 (2000), pp. 3832-3837.

[10] T. Riedl, F. Hanaoka and J.M. Egly, The comings and goings of nucleotide excision repair factors on damaged DNA, EMBO J. 22 (2003), pp. 5293-5303.

[11] K. Sugasawa, J.M. Ng, C. Masutani, S. Iwai, P.J. van der Spek, A.P. Eker, F. Hanaoka, D. Bootsma and J.H. Hoeijmakers, Xeroderma pigmentosum group $C$ protein complex is the initiator of global genome nucleotide excision repair, Mol. Cell 2 (1998), pp. 223-232.

[12] M. Volker, M.J. Mone, P. Karmakar, A. van Hoffen, W. Schul, W. Vermeulen, J.H. Hoeijmakers, R. van Driel, A.A. van Zeeland and L.H. Mullenders, Sequential assembly of the nucleotide excision repair factors in vivo, Mol. Cell 8 (2001), pp. 213-224.

[13] J.T. Reardon, D. Mu and A. Sancar, Overproduction, purification, and characterization of the XPC subunit of the human DNA repair excision nuclease, J. Biol. Chem. 271 (1996), pp. 19451-19456.

[14] K. Sugasawa, T. Okamoto, Y. Shimizu, C. Masutani, S. Iwai and F. Hanaoka, A multistep damage recognition mechanism for global genomic nucleotide excision repair, Genes Dev. 15 (2001), pp. 507-521.

[15] B.J. Hwang, J.M. Ford, P.C. Hanawalt and G. Chu, Expression of the p48 xeroderma pigmentosum gene is p53dependent and is involved in global genomic repair, Proc. Natl. Acad. Sci. U.S.A. 96 (1999), pp. 424-428.

[16] T. Tan and G. Chu, p53 Binds and activates the xeroderma pigmentosum DDB2 gene in humans but not mice, Mol. Cell Biol. 22 (2002), pp. 3247-3254.

[17] J.Y. Tang, B.J. Hwang, J.M. Ford, P.C. Hanawalt and G. Chu, Xeroderma pigmentosum p48 gene enhances global genomic repair and suppresses UV-induced mutagenesis, Mol. Cell 5 (2000), pp. 737-744.

[18] M. Wakasugi, A. Kawashima, H. Morioka, S. Linn, A. Sancar, T. Mori, O. Nikaido and T. Matsunaga, DDB accumulates at DNA damage sites immediately after UV irradiation and directly stimulates nucleotide excision repair, J. Biol. Chem. 277 (2002), pp. 1637-1640.

[19] M.E. Fitch, S. Nakajima, A. Yasui and J.M. Ford, In vivo recruitment of XPC to UV-induced cyclobutane pyrimidine dimers by the DDB2 gene product, J. Biol. Chem. 278 (2003), pp. 46906-46910. 
[20] V.A. Bohr, C.A. Smith, D.S. Okumoto and P.C. Hanawalt, DNA repair in an active gene: removal of pyrimidine dimers from the DHFR gene of CHO cells is much more efficient than in the genome overall, Cell 40 (1985), pp. 359 369.

[21] S.A. Leadon and D.A. Lawrence, Preferential repair of DNA damage on the transcribed strand of the human metallothionein genes requires RNA polymerase II, Mutat. Res. 255 (1991), pp. 67-78.

[22] I. Mellon, V.A. Bohr, C.A. Smith and P.C. Hanawalt, Preferential DNA repair of an active gene in human cells, Proc. Natl. Acad. Sci. U.S.A. 83 (1986), pp. 8878-8882.

[23] I. Mellon, G. Spivak and P.C. Hanawalt, Selective removal of transcription-blocking DNA damage from the transcribed strand of the mammalian DHFR gene, Cell 51 (1987), pp. 241-249.

241 S. Tornaletti, D. Reines and P.C. Hanawalt, Structural characterization of RNA polymerase II complexes arrested by a cyclobutane pyrimidine dimer in the transcribed strand of template DNA, J. Biol. Chem. 274 (1999), pp. $24124-$ 24130.

[25] K.A. Henning, L. Li, N. Iyer, L. McDaniel, M.S. Reagan, R. Legerski, R.A. Schultz, M. Stefanini, A.R. Lehmann, L.V. Mayne and E.C. Friedberg, The Cockayne syndrome group A gene encodes a WD repeat protein that interacts with CSB protein and a subunit of RNA polymerase II TFIIH, Cell 82 (1995), pp. 555-564.

[26] Y. Nakatsu, H. Asahina, E. Citterio, S. Rademakers, W. Vermeulen, S. Kamiuchi, J.P. Yeo, M.C. Khaw, M. Saijo, N. Kodo, T. Matsuda, J.H. Hoeijmakers and K. Tanaka, XAB2, a novel tetratricopeptide repeat protein involved in transcription-coupled DNA repair and transcription, J. Biol. Chem. 275 (2000), pp. 34931-34937.

[27] C. Troelstra, A. van Gool, J. de Wit, W. Vermeulen, D. Bootsma and J.H. Hoeijmakers, ERCC6, a member of a subfamily of putative helicases, is involved in Cockayne's syndrome and preferential repair of active genes, Cell 71 (1992), pp. 939-953.

[28] M. Yokoi, C. Masutani, T. Maekawa, K. Sugasawa, Y. Ohkuma and F. Hanaoka, The xeroderma pigmentosum group C protein complex XPC-HR23B plays an important role in the recruitment of transcription factor IIH to damaged DNA, J. Biol. Chem. 275 (2000), pp. 9870-9875.

[29] R. Drapkin, J.T. Reardon, A. Ansari, J.C. Huang, L. Zawel, K. Ahn, A. Sancar and D. Reinberg, Dual role of TFIIH in DNA excision repair and in transcription by RNA polymerase II, Nature 368 (1994), pp. 769-772.

[30] E. Evans, J.G. Moggs, J.R. Hwang, J.M. Egly and R.D. Wood, Mechanism of open complex and dual incision formation by human nucleotide excision repair factors, EMBO J. 16 (1997), pp. 6559-6573.

[31] L. Schaeffer, V. Moncollin, R. Roy, A. Staub, M. Mezzina, A. Sarasin, G. Weeda, J.H. Hoeijmakers and J.M. Egly, The ERCC2/DNA repair protein is associated with the class II BTF2/TFIIH transcription factor, EMBO J. 13 (1994), pp. 2388-2392.

[32] L. Schaeffer, R. Roy, S. Humbert, V. Moncollin, W. Vermeulen, J.H. Hoeijmakers, P. Chambon and J.M. Egly, DNA repair helicase: a component of BTF2 (TFIIH) basic transcription factor, Science 260 (1993), pp. 58-63.

[33] G.S. Winkler, S.J. Araujo, U. Fiedler, W. Vermeulen, F. Coin, J.M. Egly, J.H. Hoeijmakers, R.D. Wood, H.T. Timmers and G. Weeda, TFIIH with inactive XPD helicase functions in transcription initiation but is defective in DNA repair, J. Biol. Chem. 275 (2000), pp. 4258-4266.

[34] D. Mu, D.S. Hsu and A. Sancar, Reaction mechanism of human DNA repair excision nuclease, J. Biol. Chem. 271 (1996), pp. 8285-8294.

[35] W.L. de Laat, E. Appeldoorn, K. Sugasawa, E. Weterings, N.G. Jaspers and J.H. Hoeijmakers, DNA-binding polarity of human replication protein A positions nucleases in nucleotide excision repair, Genes Dev. 12 (1998), pp. 2598-2609.

[36] L. Li, X. Lu, C.A. Peterson and R.J. Legerski, An interaction between the DNA repair factor XPA and replication protein A appears essential for nucleotide excision repair, Mol. Cell Biol. 15 (1995), pp. 5396-5402.

[37] E. Stigger, R. Drissi and S.H. Lee, Functional analysis of human replication protein A in nucleotide excision repair, J. Biol. Chem. 273 (1998), pp. 9337-9343.

[38] J.S. You, M. Wang and S.H. Lee, Biochemical analysis of the damage recognition process in nucleotide excision repair, J. Biol. Chem. 278 (2003), pp. 7476-7485. 
[39] A. O'Donovan, A.A. Davies, J.G. Moggs, S.C. West and R.D. Wood, XPG endonuclease makes the 3' incision in human DNA nucleotide excision repair, Nature 371 (1994), pp. 432-435.

[40] A.M. Sijbers, W.L. de Laat, R.R. Ariza, M. Biggerstaff, Y.F. Wei, J.G. Moggs, K.C. Carter, B.K. Shell, E. Evans, M.C. de Jong, S. Rademakers, J. de Rooij, N.G. Jaspers, J.H. Hoeijmakers and R.D. Wood, Xeroderma pigmentosum group F caused by a defect in a structure- specific DNA repair endonuclease, Cell 86 (1996), pp. 811822.

[41] A. Aboussekhra, M. Biggerstaff, M.K. Shivji, J.A. Vilpo, V. Moncollin, V.N. Podust, M. Protic, U. Hubscher, J.M. Egly and R.D. Wood, Mammalian DNA nucleotide excision repair reconstituted with purified protein components, Cell 80 (1995), pp. 859-868.

[42] M.E. Budd and J.L. Campbell, DNA polymerases required for repair of UV-induced damage in Saccharomyces cerevisiae, Mol. Cell. Biol. 15 (1995), pp. 2173-2179.

[43] M.K. Shivji, V.N. Podust, U. Hubscher and R.D. Wood, Nucleotide excision repair DNA synthesis by DNA polymerase epsilon in the presence of PCNA, RFC, and RPA, Biochemistry 34 (1995), pp. 5011-5017.

[44] S.J. Araujo, F. Tirode, F. Coin, H. Pospiech, J.E. Syvaoja, M. Stucki, U. Hubscher, J.M. Egly and R.D. Wood, Nucleotide excision repair of DNA with recombinant human proteins: definition of the minimal set of factors, active forms of TFIIH, and modulation by CAK, Genes Dev. 14 (2000), pp. 349-359.

[45] D.E. Barnes, A.E. Tomkinson, A.R. Lehmann, A.D. Webster and T. Lindahl, Mutations in the DNA ligase I gene of an individual with immunodeficienies and cellular hypersensitivity to DNA-damaging agents, Cell 69 (1992), pp. 495-503.

[46] H. de Waard, J. de Wit, T.G. Gorgels, G. van den Aardweg, J.O. Andressoo, M. Vermeij, H. van Steeg, J.H. Hoeijmakers and G.T. van der Horst, Cell type-specific hypersensitivity to oxidative damage in CSB and XPA mice, DNA Repair (Amst) 2 (2003), pp. 13-25.

[47] J.M. Egly, The 14th Datta Lecture. TFIIH: from transcription to clinic, FEBS Lett. 498 (2001), pp. 124-128.

[48] F. Coin, J. Auriol, A. Tapias, P. Clivio, W. Vermeulen and J.M. Egly, Phosphorylation of XPB helicase regulates TFIIH nucleotide excision repair activity, EMBO J. 23 (2004), pp. 4835-4846.

[49] P. Drane, E. Compe, P. Catez, P. Chymkowitch and J.M. Egly, Selective regulation of vitamin D receptorresponsive genes by TFIIH, Mol. Cell 16 (2004), pp. 187-197.

[50] A. Keriel, A. Stary, A. Sarasin, C. Rochette-Egly and J.M. Egly, XPD mutations prevent TFIIH-dependent transactivation by nuclear receptors and phosphorylation of RARalpha, Cell 109 (2002), pp. 125-135.

[51] D. Hoogstraten, A.L. Nigg, H. Heath, L.H. Mullenders, R. van Driel, J.H. Hoeijmakers, W. Vermeulen and A.B. Houtsmuller, Rapid switching of TFIIH between RNA polymerase I and II transcription and DNA repair in vivo, Mol. Cell 10 (2002), pp. 1163-1174.

[52] S. Iben, H. Tschochner, M. Bier, D. Hoogstraten, P. Hozak, J.M. Egly and I. Grummt, TFIIH plays an essential role in RNA polymerase I transcription, Cell 109 (2002), pp. 230-297.

[53] J.W. Harper and S.J. Elledge, The role of Cdk7 in CAK function, a retro-retrospective, Genes Dev. 12 (1998), pp. 285-289.

[54] L.J. Niedernhofer, J. Essers, G. Weeda, B. Beverloo, J. de Wit, M. Muijtjens, H. Odijk, J.H. Hoeijmakers and R. Kanaar, The structure-specific endonuclease Ercc1-Xpf is required for targeted gene replacement in embryonic stem cells, EMBO J. 20 (2001), pp. 6540-6549.

[55] G.L. Dianov, T. Thybo, I.I. Dianova, L.J. Lipinski and V.A. Bohr, Single nucleotide patch base excision repair is the major pathway for removal of thymine glycol from DNA in human cell extracts, J. Biol. Chem. 275 (2000), pp. $11809-11813$

[56] S.K. Lee, S.L. Yu, L. Prakash and S. Prakash, Requirement of yeast RAD2, a homolog of human XPG gene, for efficient RNA polymerase II transcription. Implications for Cockayne syndrome, Cell 109 (2002), pp. 823-834.

[57] A.S. Balajee, L.P. De Santis, R.M. Brosh, R. Selzer and V.A. Bohr, Role of the ATPase domain of the Cockayne syndrome group B protein in UV induced apoptosis, Oncogene 19 (2000), pp. 477-489. 
[58] D.E. Brash, N.M. Wikonkal, E. Remenyik, G.T. van der Horst, E.C. Friedberg, D.L. Cheo, H. van Steeg, A. Westerman and H.J. van Kranen, The DNA damage signal for Mdm2 regulation, Trp53 induction, and sunburn cell formation in vivo originates from actively transcribed genes, J. Invest. Dermatol. 117 (2001), pp. 1234-1240.

[59] G. Conforti, T. Nardo, M. D'Incalci and M. Stefanini, Proneness to UV-induced apoptosis in human fibroblasts defective in transcription coupled repair is associated with the lack of Mdm2 transactivation, Oncogene 19 (2000), pp. 2714-2720.

[60] J. Garssen, H. van Steeg, F. de Gruijl, J. de Boer, G.T. van der Horst, H. van Kranen, H. van Loveren, M. van Dijk, A. Fluitman, G. Weeda and J.H. Hoeijmakers, Transcription-coupled and global genome repair differentially influence UV-B-induced acute skin effects and systemic immunosuppression, J. Immunol. 164 (2000), pp. 61996205.

[61] M. Ljungman and F. Zhang, Blockage of RNA polymerase as a possible trigger for u.v. light-induced apoptosis Oncogene 13 (1996), pp. 823-831.

[62] J.C. States, E.R. McDuffie, S.P. Myrand, M. McDowell and J.E. Cleaver, Distribution of mutations in the human xeroderma pigmentosum group A gene and their relationships to the functional regions of the DNA damage recognition protein, Hum. Mutat. 12 (1998), pp. 103-113.

[63] A. de Vries, C.Th. van Oostrom, F.M. Hofhuis, P.M. Dortant, R.J. Berg, F.R. de Gruijl, P.W. Wester, C.F. van Kreijl, P.J. Capel, H. van Steeg and S.J. Verbeek, Increased susceptibility to ultraviolet-B and carcinogens of mice lacking the DNA excision repair gene XPA, Nature 377 (1995), pp. 169-173.

[64] H. Nakane, S. Takeuchi, S. Yuba, M. Saijo, Y. Nakatsu, H. Murai, Y. Nakatsuru, T. Ishikawa, S. Hirota, Y. Kitamura, Y. Kato, Y. Tsunoda, H. Miyauchi, T. Horio, T. Tokunaga, T. Matsunaga, O. Nikaido, Y. Nishimune, Y Okada and K. Tanaka, High incidence of ultraviolet-B-or chemical-carcinogen-induced skin tumours in mice lacking the xeroderma pigmentosum group A gene, Nature 377 (1995), pp. 165-168.

[65] A. de Vries, C.Th. van Oostrom, P.M. Dortant, R.B. Beems, C.F. van Kreijl, P.J. Capel and H. van Steeg, Spontaneous liver tumors and benzo[a]pyrene-induced lymphomas in XPA-deficient mice, Mol. Carcinog. 19 (1997), pp. 46-53.

[66] Giese, M.E. Dollé, A. Hezel, H. van Steeg and J. Vijg, Accelerated accumulation of somatic mutations in mice deficient in the nucleotide excision repair gene XPA, Oncogene 18 (1999), pp. 1257-1260.

[67] G. Tomasevic, H.L. Laurer, G. Mattiasson, H. van Steeg, T. Wieloch, T.K. McIntosh, Delayed neuromotor recovery and increased cognitive dysfunction following experimental brain trauma in mice lacking the DNA repair gene XPA, chapter 5, Thesis, Lund University Sweden, 2000.

[68] J.H. Hoeijmakers, Genome maintenance mechanisms for preventing cancer, Nature 411 (2001), pp. 367-374.

[69] A.T. Sands, A. Abuin, A. Sanchez, C.J. Conti and A. Bradley, High susceptibility to ultraviolet-induced carcinogenesis in mice lacking XPC, Nature 377 (1995), pp. 162-165.

[70] D.L. Cheo, H.J. Ruven, L.B. Meira, R.E. Hammer, D.K. Burns, N.J. Tappe, A.A. van Zeeland, L.H. Mullenders and E.C. Friedberg, Characterization of defective nucleotide excision repair in XPC mutant mice, Mutat. Res. 374 (1997), pp. 1-9.

[71] E.C. Friedberg, J.P. Bond, D.K. Burns, D.L. Cheo, M.S. Greenblatt, L.B. Meirs, D. Nahari and A.M. Reis, Defective nucleotide excision repair in xpc mutant mice and its association with cancer predisposition, Mutat. Res. 459 (2000), pp. 99-108.

[72] M.C. Hollander, R.T. Philburn, A.D. Patterson, S. Velasco-Miguel, E.C. Friedberg, R.I. Linnoila and A.J. Fornace Jr., Deletion of XPC leads to lung tumors in mice and is associated with early events in human lung carcinogenesis, Proc. Natl. Acad. Sci. U.S.A. 102 (2005), pp. 13200-13205.

[73] D.L. Cheo, L.B. Meira, D.K. Burns, A.M. Reis, T. Issac and E.C. Friedberg, Ultraviolet B radiation-induced skin cancer in mice defective in the Xpc, Trp53, and Apex (HAP1) genes: genotype-specific effects on cancer predisposition and pathology of tumors, Cancer Res. 60 (2000), pp. 1580-1584.

[74] S.W.P. Wijnhoven, H.J. Kool, L.H. Mullenders, A.A. van Zeeland, E.C. Friedberg, G.T. van der Horst, H. van Steeg and $\mathrm{H}$. Vrieling, Age-dependent spontaneous mutagenesis in Xpc mice defective in nucleotide excision repair, Oncogene 19 (2000), pp. 5034-5037. 
[75] J. Moser, M. Volker, H. Kool, S. Alekseev, H. Vrieling, A. Yasui, A.A. van Zeeland and L.H. Mullenders, The UVdamaged DNA binding protein mediates efficient targeting of the nucleotide excision repair complex to UV-induced photo lesions, DNA Repair (2005), pp. 571-582.

[76] T. Itoh, D. Cado, R. Kamide and S. Linn, DDB2 gene disruption leads to skin tumors and resistance to apoptosis after exposure to ultraviolet light but not a chemical carcinogen, Proc. Natl. Acad. Sci. U.S.A. 101 (2004), pp. 20522057.

[77] T. Yoon, A. Chakrabortty, R. Franks, T. Valli, H. Kiyokawa and P. Raychaudhuri, Tumor-prone phenotype of DDB2-deficient mice, Oncogene 24 (2005), pp. 469-478.

[78] S. Alekseev, H. Kool, H. Rebel, M. Fousteri, J. Moser, C. Backendorf, F.R. de Gruijl, H. Vrieling and L.H.F. Mullenders, Enhanced DDB2 expression protects mice from carcinogenic effects of chronic UV-B irradiation, Cancer Res. (2005), pp. 10298-10306.

[79] J.M. Ng, H. Vrieling, K. Sugasawa, M.P. Ooms, J.A. Grootegoed, J.T. Vreeburg, P. Visser, R.B. Beems, T.G. Gorgels, F. Hanaoka, J.H. Hoeijmakers and G.T. van der Horst, Developmental defects and male sterility in mice lacking the ubiquitin-like DNA repair gene mHR23B, Mol. Cell Biol. 22 (2002), pp. 1233-1245.

[80] J.M. Ng, W. Vermeulen, G.T. van der Horst, S. Bergink, K. Sugasawa, H. Vrieling and J.H. Hoeijmakers, A novel regulation mechanism of DNA repair by damage-induced and RAD23-dependent stabilization of xeroderma pigmentosum group C protein, Genes Dev. 17 (2003), pp. 1630-1645.

[81] G.T. van der Horst, H. van Steeg, R.J. Berg, A.J. van Gool, J. de Wit, G. Weeda, H. Morreau, R.B. Beems, C.F. van Kreijl, F.R. de Gruijl, D. Bootsma and J.H. Hoeijmakers, Defective transcription-coupled repair in Cockayne syndrome B mice is associated with skin cancer predisposition, Cell 89 (1997), pp. 425-435.

[82] G.T. van der Horst, L. Meira, T.G. Gorgels, J. de Wit, S. Velasco-Miguel, J.A. Richardson, Y. Kamp, M.P. Vreeswijk, B. Smit, D. Bootsma, J.H. Hoeijmakers and E.C. Friedberg, UVB radiation-induced cancer predisposition in Cockayne syndrome group A (Csa) mutant mice, DNA Repair 1 (2002), pp. 143-157.

[83] R. Yonemasu, M. Minami, Y. Nakatsu, M. Takeuchi, I. Kuraoka, Y. Matsuda, Y. Higashi, H. Kondoh and K. Tanaka, Disruption of mouse XAB2 gene involved in pre-mRNA splicing, transcription and transcription-coupled DNA repair results in preimplantation lethality, DNA Repair 4 (2005), pp. 479-491.

[84] Y.N. Harada, N. Shiomi, M. Koike, M. Ikawa, M. Okabe, S. Hirota, Y. Kitamura, M. Kitagawa, T. Matsunaga, O. Nikaido and T. Shiomi, Postnatal growth failure, short life span, and early onset of cellular senescence and subsequent immortalization in mice lacking the xeroderma pigmentosum group G gene, Mol. Cell Biol. 19 (1999), pp. 2366-2372.

[85] X.Z. Sun, Y.N. Harada, S. Takahashi, N. Shiomi and T. Shiomi, Purkinje cell degeneration in mice lacking the xeroderma pigmentosum group G gene, J. Neurosci. Res. 64 (2001), pp. 348-354.

[86] N. Shiomi, S. Kito, M. Oyama, T. Matsunaga, Y.N. Harada, M. Ikawa, M. Okabe and T. Shiomi, Identification of the XPG region that causes the onset of Cockayne syndrome by using Xpg mutant mice generated by the cDNAmediated knock-in method, Mol. Cell Biol. 24 (2004), pp. 3712-3719.

[87] M. Tian, D.A. Jones, M. Smith, R. Shinkura and F.W. Alt, Deficiency in the nuclease activity of xeroderma pigmentosum G in mice leads to hypersensitivity to UV irradiation, Mol. Cell Biol. 24 (2004), pp. 2237-2242.

[88] J. Bradsher, J. Auriol, L.P. de Santis, S. Iben, J.L. Vonesch, I. Grummt and J.M. Egly, CSB is a component of RNA pol I transcription, Mol. Cell 4 (2002), pp. 819-829.

[89] A. Klungland, M. Hoss, D. Gunz, A. Constantinou, S.G. Clarkson, P.W. Doetsch, P.H. Bolton, R.D. Wood and T. Lindahl, Base excision repair of oxidative DNA damage activated by XPG protein, Mol. Cell 1 (1999), pp. 33-42.

[90] S.K. Lee, S.L. Yu, L. Prakash and S. Prakash, Requirement of yeast RAD2, a homolog of human XPG gene, for efficient RNA polymerase II transcription implications for Cockayne syndrome, Cell 109 (2002), pp. 823-834.

[91] J. de Boer, I. Donker, J. de Wit, J.H. Hoeijmakers and G. Weeda, Disruption of the mouse xeroderma pigmentosum group D DNA repair/basal transcription gene results in preimplantation lethality, Cancer Res. 58 (1998), pp. 89-94.

[92] J. de Boer, J. de Wit, H. van Steeg, R.J. Berg, H. Morreau, P. Visser, A.R. Lehmann, M. Duran, J.H. Hoeijmakers and G. Weeda, A mouse model for the basal transcription/DNA repair syndrome trichothiodystrophy, Mol. Cell 1 (1998), pp. 981-990. 
[93] S.W.P. Wijnhoven, R.B. Beems, M. Roodbergen, J. van den Berg, P.H. Lohman, K. Diderich, G.T. van der Horst, J. Vijg, J.H. Hoeijmakers and H. van Steeg, Accelerated aging pathology in ad libitum fed XpdTTD mice is accompanied by features suggestive of caloric restriction, DNA Repair 4 (2005), pp. 1314-1324.

[94] J. de Boer, J.O. Andressoo, J. de Wit, J. Huijmans, R.B. Beems, H. van Steeg, G. Weeda, G.T. van der Horst, W.A. van Leeuwen, N. Themmen, M. Meradji and J.H. Hoeijmakers, Premature aging in mice deficient in DNA repair and transcription, Science 296 (2002), pp. 1276-1279.

[95] E.C. Friedberg and L.B. Meira, Database of mouse strains carrying targeted mutations in genes affecting cellular responses to DNA damage, Version 5, DNA Repair 2 (2003), pp. 501-530.

[96] L.J. Niedernhofer, H. Odijk, M. Budzowska, E. van Drunen, A. Maas, A.F. Theil, J. de Wit, N.G. Jaspers, H.B. Beverloo, J.H.J. Hoeijmakers and R. Kanaar, The structure-specific endonuclease Ercc1-Xpf is required to resolve DNA interstrand cross-link-induced double-strand breaks, Mol. Cell Biol. 24 (2004), pp. 5776-5787.

[97] C.E. Schrader, J. Vardo, E. Linehan, M.Z. Twarog, L.J. Niedernhofer, J.H.J. Hoeijmakers and J. Stavnezer, Deletion of the nucleotide excision repair gene Ercc1 reduces immunoglobulin class switching and alters mutations near switch recombination junctions, J. Exp. Med. 200 (2004), pp. 321-330.

[98] J. McWhir, J. Selfridge, D.J. Harrison, S. Squires and D.W. Melton, Mice with DNA repair gene (ERCC-1) deficiency have elevated levels of p53, liver nuclear abnormalities and die before weaning, Nat. Genet. 5 (1993), pp. 217-224.

[99] G. Weeda, I. Donker, J. de Wit, H. Morreau, R. Janssens, C.J. Vissers, A. Nigg, H. van Steeg, D. Bootsma and J.H.J. Hoeijmakers, Disruption of mouse ERCC1 results in a novel reapir syndrome with growth failure, nuclear abnormalities and senescence, Curr. Biol. 7 (1997), pp. 427-439.

[100] J. Selfridge, K.T. Hsia, N.J. Redhead and D.W. Melton, Correction of liver dysfunction in DNA repair-deficient mice with an ERCC1 transgene, Nucl. Acids Res. 29 (2001), pp. 4541-4550.

[101] P. Hasty, J. Campisi, J.H.J. Hoeijmakers, H. van Steeg and J. Vijg, Aging and genome maintenance: lessons from the mouse?, Science 299 (2003), pp. 1355-1359.

[102] J.M. Prasher, A.S. Lalai, C. Heijmans-Antonissen, R.E. Ploemacher, J.H.J. Hoeijmakers, I.P. Touw and L.J. Niedernhofer, Reduced hematopoietic reserves in DNA interstrand crosslink repair-deficient Ercc $1^{-1-}$ mice, EMBO J. 24 (2005), pp. 861-871.

[103] M.D. Chipchase, M. O'Neill and D.W. Melton, Characterization of premature liver polyploidy in DNA repair (Ercc1)-deficient mice, Hepatology 38 (2003), pp. 958-966.

[104] M. Tian, R. Shinkura, N. Shinkura and F.W. Alt, Growth retardation, early death, and DNA repair defects in mice deficient for the nucleotide excision repair enzyme XPF, Mol. Cell Biol. 24 (2004), pp. 1200-1205.

[105] M. Murai, Y. Enokido, N. Inamura, M. Yoshino, Y. Nakatsu, G.T. van der Horst, J.H.J. Hoeijmakers, K. Tanaka and $\mathrm{H}$. Hatanaka, Early postnatal ataxia and abnormal cerebellar development in mice lacking Xeroderma pigmentosum Group A and Cockayne syndrome Group B DNA repair genes, Proc. Natl. Acad. Sci. U.S.A. 98 (2001), pp. 13379-13384.

[106] N. Shiomi, M. Mori, S. Kito, Y.N. Harada, K. Tanaka and T. Shiomi, Severe growth retardation and short life span of double-mutant mice lacking Xpa and exon 15 of Xpg, DNA Repair 4 (2005), pp. 351-357.

[107] Y. Lu, H. Lian, P. Sharma, N. Schreiber-Agus, R.G. Russell, L. Chin, G.T. van der Horst and D.B. Bregman, Disruption of the Cockayne syndrome B gene impairs spontaneous tumorigenesis in cancer-predisposed Ink4a/ARF knockout mice, Mol. Cell Biol. 5 (2001), pp. 1810-1818.

[108] R.J. Berg, A. de Vries, H. van Steeg and F.R. de Gruijl, Relative susceptibilities of XPA knockout mice and their heterozygous and wild-type littermates to UVB-induced skin cancer, Cancer Res. 57 (1997), pp. 581-584.

[109] R.J. Berg, H.J. Ruven, A.T. Sands, F.R. de Gruijl and L.H. Mullenders, Defective global genome repair in XPC mice is associated with skin cancer susceptibility but not with sensitivity to UVB induced erythema and edema, J. Invest. Dermatol. 110 (1998), pp. 405-409.

[110] J. de Boer, H. van Steeg, R.J. Berg, J. Garssen, J. de Wit, C.T. van Oostrum, R.B. Beems, G.T. van der Horst, C.F. van Kreijl, F.R. de Gruijl, D. Bootsma, J.H. Hoeijmakers and G. Weeda, Mouse model for the DNA repair/basal transcription disorder trichothiodystrophy reveals cancer predisposition, Cancer Res. 59 (1999), pp. 3489-3494. 
[111] R.J. Berg, H. Rebel, G.T. van der Horst, H.J. van Kranen, L.H. Mullenders, W.A. van Vloten and F.R. de Gruijl, Impact of global genome repair versus transcription-coupled repair on ultraviolet carcinogenesis in hairless mice, Cancer Res. 60 (2000), pp. 2858-2863.

[112] M.P. Vreeswijk, A. van Hoffen, B.E. Westland, H. Vrieling, A.A. van Zeeland and L.H. Mullenders, Analysis of repair of cyclobutane pyrimidine dimers and pyrimidine 6-4 pyrimidone photoproducts in transcriptionally active and inactive genes in Chinese hamster cells, J. Biol. Chem. 269 (1994), pp. 31858-31863.

[113] H.J. Ruven, C.M. Seelen, P.H. Lohman, H. van Kranen, A.A. van Zeeland and L.H. Mullenders, Strand-specific removal of cyclobutane pyrimidine dimers from the p53 gene in the epidermis of UVB-irradiated hairless mice, Oncogene 9 (1994), pp. 3427-3432.

[114] E.M. Hoogervorst, W. Bruins, E. Zwart, C.T. van Oostrom, G.J. van den Aardweg, R.B. Beems, J. van den Berg, T. Jacks, H. van Steeg and A. de Vries, Lack of p53 Ser389 phosphorylation predisposes mice to develop 2acetylaminofluorene-induced bladder tumors but not ionizing radiation-induced lymphomas, Cancer Res. 65 (2005), pp. 3610-3616.

[115] A.M. Reis, D.L. Cheo, L.B. Meira, M.S. Greenblatt, J.P. Bond, D. Nahari and E.C. Friedberg, Genotype-specific Trp53 mutational analysis in ultraviolet B radiation-induced skin cancers in Xpc and Xpc Trp53 mutant mice, Cancer Res. 60 (2000), pp. 1571-1579.

[116] S. Kanjilal, W.E. Pierceall, K.K. Cummings, M.L. Kripke and H.N. Ananthaswamy, High frequency of p53 mutations in ultraviolet radiation-induced murine skin tumors: evidence for strand bias and tumor heterogeneity, Cancer Res. 53 (1993), pp. 2961-2964.

[117] S. Kress, C. Sutter, P.T. Strickland, H. Mukhtar, J. Schweizer and M. Schwarz, Carcinogen-specific mutationa pattern in the p53 gene in ultraviolet B radiation-induced squamous cell carcinomas of mouse skin, Cancer Res. 52 (1992), pp. 6400-6403.

[118] H.J. van Kranen, F.R. de Gruijl, A. de Vries, Y. Sontag, P.W. Wester, H.C. Senden, E. Rozemuller and C.F. van Kreijl, Frequent $p 53$ alterations but low incidence of ras mutations in UV-B-induced skin tumors of hairless mice, Carcinogenesis 16 (1995), pp. 1141-1147.

[119] N. Dumaz, H.J. van Kranen, A. de Vries, R.J. Berg, P.W. Wester, C.F. van Kreijl, A. Sarasin, L. Daya-Grosjean and F.R. de Gruijl, the role of UV-B light in skin carcinogenesis through the analysis of p53 mutations in squamous cell carcinomas of hairless mice, Carcinogenesis 18 (1997), pp. 897-904.

[120] H.N. Ananthaswamy, A. Ouhtit, R.L. Evans, A. Gorny, P. Khaskina, A.T. Sands and C.J. Conti, Persistence of p53 mutations and resistance of keratinocytes to apoptosis are associated with the increased susceptibility of mice lacking the XPC gene to UV carcinogenesis, Oncogene 18 (1999), pp. 7395-7398.

[121] A.A. van Zeeland, M.P. Vreeswijk, F.R. de Gruijl, H.J. van Kranen, H. Vrieling and L.F. Mullenders, Transcription-coupled repair: impact on UV-induced mutagenesis in cultured rodent cells and mouse skin tumors, Mutat. Res. 577 (2005), pp. 170-178.

[122] S. Takeuchi, Y. Nakatsu, H. Nakane, H. Murai, S. Hirota, Y. Kitamura, A. Okuyama and K. Tanaka, Strand specificity and absence of hot spots for p53 mutations in ultraviolet B-induced skin tumors of XPA-deficient mice, Cancer Res. 58 (1998), pp. 641-646.

[123] A. de Vries, R.J. Berg, S. Wijnhoven, A. Westerman, P.W. Wester, C.F. van Kreijl, P.J. Capel, F.R. de Gruijl, $\mathrm{H}$.J. van Kranen and $\mathrm{H}$. van Steeg, XPA-deficiency in hairless mice causes a shift in skin tumor types and mutational target genes after exposure to low doses of U.V.B, Oncogene 16 (1998), pp. 2205-2212.

[124] Y. Takahashi, Y. Nakatsuru, S. Zhang, Y. Shimizu, H. Kume, K. Tanaka, F. Ide and T. Ishikawa, Enhanced spontaneous and aflatoxin-induced liver tumorigenesis in xeroderma pigmentosum group A gene-deficient mice, Carcinogenesis 23 (2002), pp. 627-633.

[125] E.M. Hoogervorst, C.T. van Oostrom, R.B. Beems, J. van Benthem, S. Gielis, J.P. Vermeulen, P.W. Wester, J.G. Vos, A. de Vries and H. van Steeg, p53 heterozygosity results in an increased 2-acetylaminofluorene-induced urinary bladder but not liver tumor response in DNA repair-deficient Xpa mice, Cancer Res. 64 (2004), pp. 51185126.

[126] E.M. Hoogervorst, C.T. Van Oostrom, R.B. Beems, J. van Benthem, J. van den Berg, C.F. van Kreijl, J.G. Vos, A. de Vries and $\mathrm{H}$. van Steeg, 2-AAF-induced tumor development in nucleotide excision repair-deficient mice is associated with a defect in global genome repair but not with transcription coupled repair, DNA Repair (Amst) 4 (2005), pp. 3-9. 
[127] D.L. Cheo, D.K. Burns, L.B. Meira, J.F. Houle and E.C. Friedberg, Mutational inactivation of the xeroderma pigmentosum group $\mathrm{C}$ gene confers predisposition to 2-acetylaminofluorene-induced liver and lung cancer and to spontaneous testicular cancer in Trp53-/- mice, Cancer Res. 59 (1999), pp. 771-775.

[128] M.F. van Oosterwijk, R. Filon, W.H. Kalle, L.H. Mullenders and A.A. van Zeeland, The sensitivity of human fibroblasts to $\mathrm{N}$-acetoxy-2-acetylaminofluorene is determined by the extent of transcription-coupled repair, and/or their capability to counteract RNA synthesis inhibition, Nucl. Acids Res. 24 (1996), pp. 4653-4659.

[129] A.F. Frijhoff, C.A. Krul, A. de Vries, M.C. Kelders, G. Weeda, H. van Steeg and R.A. Baan, influence of nucleotide excision repair on $\mathrm{N}$-hydroxy-2-acetylaminofluorene-induced mutagenesis studied in lambda lacZtransgenic mice, Environ. Mol. Mutagen. 31 (1998), pp. 41-47.

[130] C.T. van Oostrom, M. Boeve, J. van Den Berg, A. de Vries, M.E. Dolle, R.B. Beems, C.F. van Kreijl, J. Vijg and $\mathrm{H}$. van Steeg, Effect of heterozygous loss of p53 on benzo[a]pyrene-induced mutations and tumors in DNA repairdeficient XPA mice, Environ. Mol. Mutagen. 34 (1999), pp. 124-130.

[131] S.A. Bol, H. Van Steeg, J.G. Jansen, C. Van Oostrom, A. de Vries, A.J. de Groot, A.D. Tates, H. VrielinG, A.A. van Zeeland and L.H. Mullenders, Elevated frequencies of benzo(a)pyrene-induced Hprt mutations in internal tissue of XPA-deficient mice, Cancer Res. 58 (1998), pp. 2850-2856.

[132] A. de Vries, M.E. Dolle, J.L. Broekhof, J.J. Muller, E.D. Kroese, C.F. van Kreijl, P.J. Capel, J. Vijg and H. van Steeg, Induction of DNA adducts and mutations in spleen, liver and lung of XPA-deficient/lacZ transgenic mice after oral treatment with benzo[a]pyrene: correlation with tumour development, Carcinogenesis 18 (1997), pp. 2327-2332.

[133] S.A. Bol, H. van Steeg, C.T. van Oostrom, A.D. Tates, H. Vrieling, A.J. de Groot, L.H. Mullenders, A.A. van Zeeland and J.G. Jansen, Nucleotide excision repair modulates the cytotoxic and mutagenic effects of N-n-butyl-Nnitrosourea in cultured mammalian cells as well as in mouse splenocytes in vivo, Mutagenesis 14 (1999), pp. 317322.

[134] S.W. Wijnhoven, H.J. Kool, C.T. van Oostrom, R.B. Beems, L.H. Mullenders, A.A. van Zeeland, G.T. van der Horst, $\mathrm{H}$. Vrieling and $\mathrm{H}$. van Steeg, The relationship between benzo[a]pyrene-induced mutagenesis and carcinogenesis in repair-deficient Cockayne syndrome group B mice, Cancer Res. 60 (2000), pp. 5681-5687.

[135] F. Ide, N. lida, Y. Nakatsuru, H. Oda, K. Tanaka and T. Ishikawa, Mice deficient in the nucleotide excision repair gene XPA have elevated sensitivity to benzo[a]pyrene induction of lung tumors, Carcinogenesis 21 (2000), pp. 12631265.

[136] E.M. Hoogervorst, A. de Vries, R.B. Beems, C.T. van Oostrom, P.W. Wester, J.G. Vos, W. Bruins, M. Roodbergen, F.R. Cassee, J. Vijg, F.J. van Schooten and H. van Steeg, Combined oral benzo[a]pyrene and inhalatory ozone exposure have no effect on lung tumor development in DNA repair-deficient Xpa mice, Carcinogenesis 24 (2003), pp. 613-619.

[137] C.F. van Kreijl, P.A. McAnulty, R.B. Beems, A. Vynckier, H. van Steeg, R. Fransson-Steen, C.L. Alden, R. Forster, J.W. van der Laan and J. Vandenberghe, Xpa and Xpa/p53+/- knockout mice: overview of available data, Toxicol. Pathol. 29 (2001) (Suppl.), pp. 117-127. 